\title{
Universal Exceptionalism in International Law
}

\author{
Anu Bradford \& Eric A. Posner
}

Table of Contents

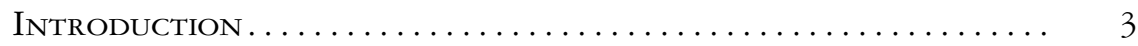

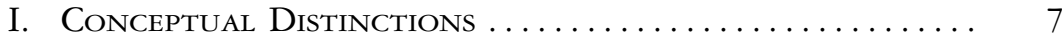

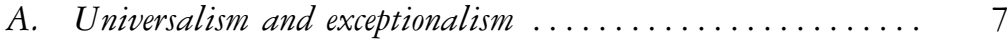

B. The standard view: American exceptionalism and European

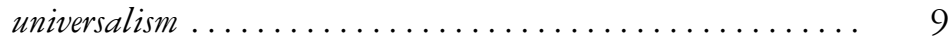

C. Multiple exceptionalisms ...................... 12

II. European Exceptionalism: The Pacifist Social Welfare

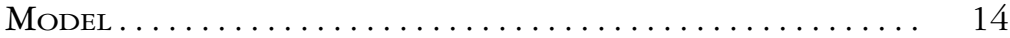

A. European exceptionalism defined ................... 14

1. Human rights .......................... 14

2. Social welfare........................ 16

3. Pooling sovereignty ..................... 18

4. Presumptive pacifism ..................... 19

B. Explaining European exceptionalism................ 21

1. Domestic policy preferences: social welfare, buman rights, and pacifism ......................... 21

2. Institutional structure ..................... 23

III. Chinese Exceptionalism: Minimalist

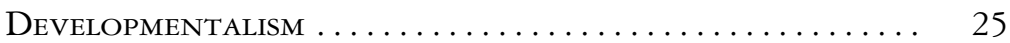

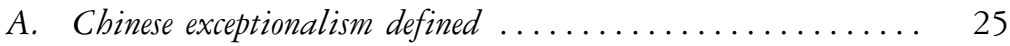

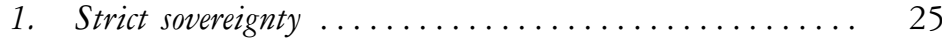

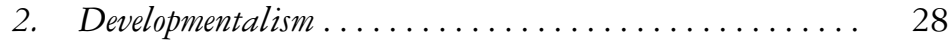

B. Explaining Chinese exceptionalism ............... 31

1. Domestic policy preferences: economic growth and reduction

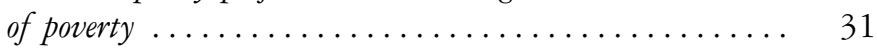

2. Institutional structure: authoritarianism .......... 33

IV. American Exceptionalism Revisited: Pro-Market

Democracy ............................... 35

A. American exceptionalism defined ................. 35

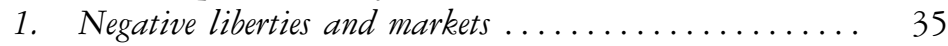

2. Military force to maintain global order.......... 38

B. Explaining American exceptionalism ............... 40

1. Domestic policy preferences: markets, liberty, democracy... 40

2. Institutions: populist democracy and powerful military... 41 
V. Are Exceptionalist States also Exemptionalist? ...... 44

A. Rejecting American, European and Chinese exemptionalism ... 44

B. Exemptionalism and violation of international law ........ 47

C. Embedded exemptionalism in international law .......... 49

VI. Conclusion .............................. 53 


\title{
Universal Exceptionalism in International Law
}

\author{
Anu Bradford \& Eric A. Posner*
}

\begin{abstract}
A trope of international law scholarship is that the United States is an "exceptionalist" nation, one that takes a distinctive (frequently hostile, unilateralist, or hypocritical) stance toward international law. However, all major powers are similarly "exceptionalist," in the sense that they take distinctive approaches to international law that reflect their values and interests. We illustrate these arguments with discussions of China, the European Union, and the United States. Charges of international-law exceptionalism betray an undefended assumption that one particular view of international law (for scholars, usually the European view) is universally valid.
\end{abstract}

\section{INTRODUCTION}

Among international lawyers, it has long been conventional wisdom that the United States acts differently from other states. In the nineteenth century, it kept to itself, refusing to participate in the wars and alliances that preoccupied European powers. In the twentieth century, it arrogated for itself the role of global leader. After World War II, the United States was the primary force behind the construction of all the major international institutions: the United Nations, including its human rights regime; the General Agreement on Tariffs and Trade ("GATT") and its evolution into the World Trade Organization ("WTO"); the development and financial institutions such as the World Bank and the International Monetary Fund ("IMF"); and the security arrangement embodied by the North Atlantic Treaty Organization ("NATO"). With the collapse of the Soviet Union, the United States was transformed from one of two superpowers into the sole hyperpower.

And yet the United States has, throughout this entire period, showed ambivalence toward international law. More than any other state, the United States put financial and diplomatic resources into advancing human rights, ${ }^{1}$ yet it refused to ratify most of the major human rights treaties, and has committed major human rights violations, including torture in its operations against $\mathrm{Al}$ Qaeda. It promoted the international trade system yet has engaged in protectionist measures. It hosts the United Nations and is its

* Assistant Professor of Law and Kirkland \& Ellis Professor of Law, University of Chicago Law School. Thanks to Daniel Abebe, Gabby Blum, Curtis Bradley, William Burke-White, Ruoying Chen, Tom Ginsburg, Jack Goldsmith, Katerina Linos, Darryl Robinson, Joel Trachtman, and participants in a seminar at Queen's University, for helpful comments, and to Charles Woodworth, James Kraehenbuehl, and Hanna Chung for research assistance.

1. See Andrew Moravcsik, The Paradox of U.S. Human Rights Policy, in American Exceptionalism and Human Rights 147 (Michael Ignatieff ed., 2005). 
largest dues-payer, yet it has violated the U.N. Charter by launching wars without U.N. Security Council ("Security Council”) approval, and frequently has been in arrears on its dues. It helped negotiate a number of important treaties-including the Law of the Sea Convention, the Rome Statute, which created the International Criminal Court ("ICC"), and the Vienna Convention on Treaties - and then refused to ratify them. It has resisted numerous efforts to strengthen the laws of war and to ban weapons such as landmines. As a result, the United States has undermined or seriously weakened the international order it has helped to create and has earned the resentment of countries not powerful enough to treat international law as an à la carte menu-or so it is said. ${ }^{2}$

In recent years, scholars have searched for explanations for this apparently distinctive stance toward international law. The usual political science theories of state behavior assume that states act in roughly the same way. States might have different capacities and populations, but they all seek to maximize their security (as the realists argue ${ }^{3}$ ) or to enhance national welfare (as rational institutionalists argue $\left.{ }^{4}\right)$. So the recent literature has sought explanations for America's distinctive international behavior in the unique attributes of the United States.

The most common explanation today appeals to a long line of literature on "American exceptionalism." 5 This literature, which goes back to Alexis de Tocqueville's Democracy in America, holds that the United States is different from all other countries. ${ }^{6}$ In Tocqueville's time, the United States was the only large country with authentic democratic institutions. Today, most countries are democracies, but the United States remains distinctive among them. Ideologically, the United States is more committed to democracy (as opposed to rule by the elites), equality of opportunity (as opposed to equality of outcomes), individualism (as opposed to collectivism), and the free market. ${ }^{7}$ Culturally, Americans are more religious, more skeptical of authority, more militaristic, and more patriotic. ${ }^{8}$ Institutionally, the country is

2. For the bill of particulars, see, for example, Michael Ignatieff, Introduction: American Exceptionalism and Human Rights, in American Exceptionalism and Human Rights 1, 1-3 (Michael Ignatieff ed., 2005); Harold H. Koh, On American Exceptionalism, 55 Stan. L. Rev. 1479, 1480-83 (2003); Anne Peters, Compensatory Constitutionalism: The Function and Potential of Fundamental International Norms and Structures, 19 Leiden J. Int'L L. 579, 604-05 (2006); Peter Spiro, The New Sovereigntists: American Exceptionalism and Its False Prophets, Foreign Aff., Nov.-Dec. 2000, at 9-13.

3. See, e.g., John J. Mearsheimer, The Tragedy of Great Power Politics 29-40 (2001).

4. See, e.g., Robert O. Keohane, After Hegemony: Cooperation and Discord in the World Political Economy (1984); see also Robert O. Keohane \& Lisa L. Martin, The Promise of Institutionalist Theory, 20 INT'L SEC. 39 (1995).

5. See, e.g., Ignatieff, supra note 2.

6. See generally Alexis de Tocqueville, Democracy in America (Harvey C. Mansfield \& Delba Winthrop eds., trans., Univ. Chi. Press 2000 1st ed. 2000) (1835, 1840).

7. See generally Seymour Martin Lipset, American Exceptionalism: A Double-Edged Sword (1996).

8. See generally id. 
more decentralized, more legalistic, and more open to democratic participation. ${ }^{9}$

How might American exceptionalism explain America's international behavior? One argument is that Americans believe that the United States, as the world's preeminent nation, perhaps one with a unique mission to promote freedom and democracy, cannot be required to submit to international institutions. ${ }^{10}$ Another is that Americans are less liberal than people in other countries, and thus oppose international legal change that liberalizes international relations too extensively. ${ }^{11}$ Other explanations appeal to distinctive attributes of American political institutions-for example, federalism and the high bar for ratifying treaties. ${ }^{12}$

In this paper, we attack the premise of these arguments. The American stance toward international law is not distinctive or exceptional-or, put differently, the United States is no more exceptional than any other powerful country. When creating international norms, powerful nations characteristically advance interpretations of international law that reflect their values and advance their interests. Similarly, powerful nations' willingness to ratify or comply with international norms hinges on the consistency of those norms with their values and interests. This type of "exceptionalism" is therefore not the exclusive preserve of one state. Today, the United States, China, and the European Union ("EU") advance conflicting interpretations of international law. During the Cold War, the United States and the Soviet Union did the same. ${ }^{13}$ The focus on American exceptionalism blinds scholars to the similar behavior occurring elsewhere. ${ }^{14}$

We further argue that international law is best understood as an overlapping consensus of the otherwise "exceptional" views of the great powers. At the core are legal norms to which virtually every nation considers itself bound. Outside the core, there is conflict. In this area of conflict, nations make inconsistent claims as to the meaning of international law. It is a

9. See Jed Rubenfeld, Unilateralism and Constitutionalism, 79 N.Y.U. L. Rev. 1971, 1993-95 (2004).

10. See Eyal Benvenisti, The US and the Use of Force: Double-edged Hegemony and the Management of Global Emergencies, 15 Eur. J. INT'L L. 677, 688 (2004); Steven G. Calabresi, "A Shining City on a Hill": American Exceptionalism and the Supreme Court's Practice of Relying on Foreign Law, 86 B.U. L. Rev. 1335, 1396-97 (2006).

11. See Calabresi, supra note 10, at 1337-38, 1389-92; Ignatieff, supra note 2; cf. Anne-Marie Slaughter, International Law in a World of Liberal States, 6 Eur. J. INT'L L. 503 (1995).

12. See Oona Hathaway, Treaties' End: The Past, Present, and Future of International Lawmaking in the United States, 117 Yale L.J. 1236, 1307-12 (2008).

13. Some distinctive doctrines of the Soviet view included, at various times: (1) the right to repudiate treaty obligations after a socialist revolution; (2) the right to intervene to assist a socialist revolution; and (3) the right to intervene in capitalist countries that fail to protect workers' rights. See generally Kazimierz Grzybowski, Soviet Public International Law: Doctrines and Diplomatic Practice (1970); Tarja Langström, Transformation in Russia and International Law 50-117 (2003).

14. A typical view is that Europeans, unlike Americans, do not have the power to pursue their values in international law because they are too weak. See, e.g., Stanley Hoffman, American Exceptionalism: The New Version, in American Exceptionalism and Human Rights 225, 225-26 (Michael Ignatieff ed., 2005). We disagree with this premise. 
significant mistake for scholars to accept the claims of any one nation as to the meaning of international law in this disputed area. It is also a mistake to dismiss a nation's interpretation of a treaty, for example, as automatically wrong. As long as nations disagree about the meaning of treaties and other sources of international law, the content of international law remains unsettled.

This argument is not entirely new, though it seems to have been forgotten. Hans Morgenthau's influential realist treatise, Politics Among Nations, notes in passing that all nations interpret or "misinterpret" international law so as to advance their ends, but he makes an exception for "codifications," which we reject. ${ }^{15}$ States offer self-interested interpretations of codes and treaties just as they do for customary international law, which was the focus of Morgenthau's discussion. Lassa Oppenheim's treatise on international law notes, but ultimately rejects, attacks on the universality of international law by commentators who argued that distinctive Soviet and German versions of international law existed between the two world wars. "These and similar intrusions of national policies into the sphere of International Law are essentially transient," Oppenheim argues. ${ }^{16} \mathrm{We}$ argue, by contrast, that disagreements about international law among the great powers are persistent and of great significance, although, as noted, a core of overlapping consensus does exist.

This paper describes the different "exceptionalisms" of the United States, China, and the EU. For each state, we trace their "exceptional" international behavior to their "exceptional" domestic interests, values, and institutions. While it is sometimes assumed that the European position on international law is in fact the correct position on international law, ${ }^{17}$ we argue that, in fact, the European position is just one among many approaches to international law that reflect a mixture of national self-interest and national (as opposed to universal) values. The United States looks less distinctive when compared to the world as a whole, than when it is compared only to the European democracies. Each exceptionalist state advances a particular version of international law that must be judged on its merits against some standard of morality; the accusation of exceptionalism is a straw-man attack. ${ }^{18}$

15. Hans J. Morgenthau, Politics Among Nations: The Struggle for Power and Peace 298-99 (Kenneth Thompson ed., Knopf 1985) (1948). Codifications refer to laws that have been codified and published in written form (for example, federal statutes in the United States or civil codes in many civil law jurisdictions). Codifications can be contrasted to judge-made common law.

16. Lassa Oppenheim, International Law: A Treatise 56 (Hersch Lauterpacht ed., 7th ed. 1948).

17. See, e.g., our discussion of Michael Ignatieffs views, infra Part I.B.

18. In the modern legal literature, the lone example of this view that we have found is Sabrina Safrin, The Un-Exceptionalism of U.S. Exceptionalism, 41 VAND. J. TRANSNAT'L L. 1307 (2008) (arguing that the U.S. stance on international law is not exceptional). Our argument builds on her work. Some skepticism about the usefulness of the notion of American exceptionalism in international law can also be found in Michael A. Newton, Exceptional Engagement: Protocol I and a World United Against Terrorism, 45 Tex. INT'L L.J. 323 (2009). 
Our argument is descriptive, not normative. We do not argue that any country's view of international law is the correct one.

\section{Conceptual Distinctions}

\section{A. Universalism and exceptionalism}

By universalism, we refer to the view that the rules of international law apply to all states. By exceptionalism, we refer to the view that the values of one particular country should be reflected in the norms of international law. By exemptionalism, we refer to the claim that the rules of international law, or of certain international treaties, should apply to all states except for one particular state. ${ }^{19}$

At one time, international law consisted of a set of contracts typically involving pairs of states, along with some general norms of customary international law that were derived from state practice and the official statements of governments and other state institutions. ${ }^{20}$ Occasional multilateral treaties would address the resolution of military conflicts involving multiple states such as the Napoleonic and Crimean Wars. ${ }^{21}$ In the twentieth century, all this changed. Although states continued to enter bilateral treaties, they increasingly established fora-notably, the United Nations-for negotiating treaties involving issues of global concern, including the laws of war, human rights, protection of the environment, trade, and regulation of the seas. $^{22}$ All states would be invited to send delegates to these conventions, and the expectation was always that the treaty obligations would be the same for all states, large and small, rich and poor. ${ }^{23}$

These practices have helped established a presumption of universalism. Once a global problem is identified, it is understood that an international solution binding all states should be sought. To be sure, states may continue to negotiate bilateral and regional agreements to address narrow cross-border and regional problems, but these agreements, though numerous, must be consistent with states' obligations under multilateral treaties.

We use the term "exceptionalism" to refer to the attitude of a state that believes that it is a model or leader in international relations because of its unique attributes. The state may hold that its institutions are the best in the world, or that it has a historical mission-and for these reasons, the state's commitments should be the world's commitments as well. Exceptionalism does not imply exemptionalism. An exceptional state may choose to comply with the rules of international law with which it disagrees. If it does violate

19. See Ignatieff, supra note 2, at 4. The term "exemptionalism" is his.

20. See Stephen C. Neff, A Short History of International Law, in International Law 31, 40-41 (Malcolm D. Evans ed., 2003).

21. See id. at 37-49.

22. See id. at $52-56$.

23. See id. 
the rules of international law, or some of those rules, it argues that those rules are inconsistent with international law properly understood. In doing so, it typically claims that some alternative rules should apply to all states equally, including itself. Thus, exceptional states need not abandon universalism, and indeed they rarely do. The exceptional state need not take the next step of exemptionalism, and argue that the rules apply to all other states but not itself. As we will see, this distinction is crucial; exceptional states are often accused of exemptionalism, in most instances inaccurately.

To understand this difference, compare two arguments often made about the U.S. attitude toward international law. Some people argue that the United States should be exempted from certain types of international criminal jurisdiction because America sends soldiers around the world to promote democracy and keep the peace. ${ }^{24}$ This argument is exemptionalist. The United States has not made this argument; instead, it has sought safeguards on criminal jurisdiction - such as the precondition of Security Council authorization before the ICC can launch investigations ${ }^{25}$ - that ensure that no state taking proper steps to uphold the international order will find its citizens in an international court. Thus, the United States has not argued that it ought to be exempted from the rules. ${ }^{26}$ Instead, it has insisted-consistent with exceptionalism-that American norms and practices should provide the basis for international law.

Exceptional states - which are always great powers, although not all great powers are exceptional states-characteristically advance universalistic views of international law that embody those states' exceptional norms. We can distinguish two stages at which this occurs. First, exceptional states attempt to influence the development of international norms during treaty negotiations, so that international law reflects their values and interests. Exceptional states are hardly alone in this respect, but because of their greater power, they are more often successful, thus generating resentment among other states. Second, exceptional states attempt to influence the development of international norms at the stage of compliance. They often assert interpretations of existing treaty obligations that reflect their values and interests, in some cases following up these interpretations with actions that

24. See 147 Cong. Rec. 18,231-32 (2001) (statement of Sen. Jesse Helms) (supporting a bill aimed at hindering the International Criminal Court, because the United States "owe[s] it . . to our men and women representing this country, both in the military and in civilian agencies," as they "get ready for a long campaign against global terrorists," to protect their actions from U.N. "second-guessing").

25. See David J. Scheffer, U.S. Ambassador at Large for War Crimes Issues, Address before the Carter Center in Atlanta, GA: U.S. Policy and the Proposed Permanent International Criminal Court (Nov. 13, 1997), available at http://www.amicc.org/docs/Scheffer11_13_97.pdf (explaining the U.S. position on ICC jurisdiction to be that the "[United Nations] Security Council should have an essential role to play in a trigger mechanism").

26. The United States does benefit from its veto in the Security Council, and in this sense one might argue that it seeks a system in which other states are bound to norms that it can avoid-de facto. We discuss this argument in Part V.C, infra. 
other states regard as violations of international law. Again, normal states do this as well, but exceptional states are far more aggressive and successful.

\section{B. The standard view: American exceptionalism and European universalism}

Consider this seeming paradox: the United States has been the leader in advancing human rights around the world since 1945, and yet at the same time it has both violated human rights itself and coddled tyrants who violate rights. The United States led the way with the Universal Declaration of Human Rights, the United Nations, and the International Covenant for Civil and Political Rights ("ICCPR"), ${ }^{27}$ and has put economic and military pressure on human-rights violating states-far more than any other state has. ${ }^{28}$ But it has also, to quote Michael Ignatieff,

supported rights-abusing regimes from Pinochet's Chile to Suharto's Indonesia; sought to scuttle the International Criminal Court, the capstone of an enforceable global human rights regime; maintained practices - like capital punishment-at variance with the human rights standards of other democracies; engaged in unilateral preemptive military actions that other states believe violate the UN Charter; failed to ratify the Convention on the Rights of the Child and the Convention on the Elimination of Discrimination Against Women; and ignored UN bodies when they criticized U.S. domestic rights practices. ${ }^{29}$

This seemingly inconsistent behavior has reinforced a perception of the prevalence of American exceptionalism. ${ }^{30}$ Of course, many other countries have engaged in the same practices; what makes the United States exceptional is that it also is a global human rights leader.

There are three strands of American exceptionalism. First, the United States negotiates human rights treaties but ratifies them subject to reservations that cut back on the scope of its obligations, fails to ratify them, or ratifies but violates them. For instance, Ignatieff argues that the United States' decision to attach conditions to its ratification to the ICCPR, a major human rights treaty, betrays exemptionalism. ${ }^{31}$ However, as Curtis Bradley

27. Sarah H. Cleveland, Norm Internalization and U.S. Economic Sanctions, 26 YALE J. INT'L L. 1, 30 (2001).

28. See id. at 4-5, 4 n.6 (describing the United States as "by far the most active player" in imposing sanctions in order to promote human rights).

29. Ignatieff, supra note 2 , at 2 .

30. Foreign leaders have been quick to condemn the United States' behavior as exceptionalist, accusing the United States of embracing international norms selectively. See, e.g., Ambassador Qiao Zonghuai, Head of Chinese Delegation to the United Nations, Statement before Vote on Draft Resolution Entitled "Situation of Human Rights in China" (Apr. 23, 1999), available at http://www.china-un.ch/eng/rqrd/ jblc/t85086.htm (condemning a resolution on Chinese human rights violations as an example of American "double standards and the politicization of human rights" as evident from the United States' own human rights violations and refusal or delay to sign and ratify international human rights treaties).

31. Ignatieff, supra note 2 , at 5-6. 
and Jack Goldsmith have pointed out, virtually all Western states have acted similarly; usually it is the authoritarian states that do not bother to add reservations to human rights treaties which they then ignore. ${ }^{32}$ Ignatieff also notes that when the United States ratifies human rights treaties, it typically provides that the provisions of the treaties are not binding as a matter of domestic law. ${ }^{33}$ However, this is a difference of form, not substance. In many states international treaties do not enter domestic law without an independent legislative act and the use of explicit provisions saying as much are unnecessary.

So if the United States is exemptionalist in Ignatieff s sense, then so are many other states. In fact, Ignatieff defines exemptionalism so broadly that it loses its meaning. In the narrow sense in which we use it, none of the examples discussed by Ignatieff count as exemptionalism because in none of these examples did the United States claim that rules should apply to others and not to itself. What is distinctive about the United States is that it rejected rules favored by other states, refused to compromise, and instead argued that all states (including the United States itself) should be subject to the rules that the United States preferred. This is classic exceptionalism, not exemptionalism. As we will see, other states engage in similar exceptionalist behavior.

Second, the United States condemns enemies for human rights violations that the United States itself commits, and turns a blind eye to friends who engage in the same behavior. This point has been made most forcefully in the international law literature by Harold Koh, who calls this type of exceptionalist behavior the use of double standards. ${ }^{34}$ However, the use of double standards is not distinctive behavior of exceptionalist states. Indeed, double standards compromise exceptionalism; the exceptionalist state believes that its institutions embody the best rules and those rules should apply to all, equally. Double standards are better seen as the result of pragmatism (at best) or inconsistent preferences (at worst), and characterize the behavior of all states, not just exceptionalist states. A state that seeks to advance human rights finds that this policy conflicts with other interests, including trade and security. The state might be willing to compromise its ideals in order to satisfy the demands of interest groups or inconsistent public preferences. It might believe that in some settings security interests will advance human rights more than a consistent line on human rights. When the United States applies double standards, it simply acts like any other state. ${ }^{35}$

32. See Curtis A. Bradley \& Jack L. Goldsmith, Treaties, Human Rights, and Conditional Consent, 149 U. PA. L. Rev. 399, 460 (2000); see also Arthur Rovine, Defense of Declarations, Reservations, and Understandings, in U.S. Ratification of the Human Rights Treaties: With or Without Reservations? 54, 57-59 (Richard B. Lillich ed., 1981).

33. Ignatieff, supra note 2 , at 14 .

34. Koh, supra note 2, at 1485-87.

35. See discussion infra Parts II, III. 
Third, Ignatieff asserts that American courts do not pay much attention to foreign judicial rulings when interpreting U.S. constitutional law and, more generally, American constitutional norms are outside the international mainstream, or at least the mainstream of developed and democratic states. ${ }^{36}$ The judiciaries in foreign democracies are more likely to cite foreign courts than American courts are. ${ }^{37}$ And most states have constitutionalized positive or social rights-including rights to health care, to work, and to education-while the United States has not. ${ }^{38}$ Most democratic states have also rejected the death penalty and have weaker protections for speech and religious association than the United States does. This refusal to go along with other democratic states can be seen as another manifestation of American exceptionalism-here, within the realm of judicial behavior and constitutionalism.

Of course, not all states are democratic. A large minority of states are authoritarian, and many formally democratic states are either not democratic - the elites pull the strings behind the scenes-or are unstable, and cycle between democracy and dictatorship. The question arises why Ignatieff compares the United States to other democratic states, and indeed he clearly has in mind the major European democracies, plus Australia, Canada, and New Zealand, and a handful of other states such as India and South Africa. These states amount to less than a quarter of the nearly 200 states in existence. Ignatieff himself admits that he understands American exceptionalism against the practices of other democratic states. ${ }^{39}$

After a survey of possible reasons for American exceptionalism, Ignatieff concludes that the most plausible explanation is that Americans are just not strongly committed to liberalism. ${ }^{40}$ Assuming his diagnosis is correct, here again Ignatieff does not pause to consider whether international law in fact embodies liberalism as he understands it - that is, liberalism understood on the European social-democratic model. The answer is surely no. Consider the top twenty most populous states in the world (in order): China, India, the

36. Ignatieff, supra note 2, at 4; see also Calabresi, supra note 10, at 1405-06.

37. Despite the ferocity of the normative debate over whether American courts should cite foreign court decisions, no study directly compares the frequency with which courts in the United States cite foreign cases relative to foreign courts. However, the general consensus among scholars is that courts in the United States cite foreign sources much less frequently than do courts outside of its borders. For an empirical assessment of the extent to which American courts cite foreign cases, see David T. Zaring, The Use of Foreign Decisions by Federal Courts: An Empirical Analysis, 3 J. Empirical Legal STud. 297 (2006) (finding that the lower federal courts rarely cite to foreign decisions). In contrast, scholars have noted the frequency with which courts outside of the United States cite foreign cases. See, e.g., C.L. Ostberg, Matthew E. Wetstein \& Craig R. Ducat, Attitudes, Precedents and Cultural Change: Explaining the Citation of Foreign Precedents by the Supreme Court of Canada, 34 Canadian J. Pol. ScI. 377 (2001) (finding that the Canadian Supreme Court often cites foreign cases, especially when interpreting the Canadian Charter of Rights and Freedoms).

38. Mary Ann Glendon, Rights in Twentieth-Century Constitutions, 59 U. CHI. L. Rev. 519, 521 (1992).

39. See Ignatieff, supra note 2 , at 4.

40. Id. at 20; see also Andrew Moravcsik, The Paradox of U.S. Human Rights Policy, in American Exceptionalism and Human Rights, supra note 2, at 147, 150 (giving a related argument that emphasizes American institutions and institutional history). 
United States, Indonesia, Brazil, Pakistan, Bangladesh, Nigeria, Russia, Japan, Mexico, the Philippines, Vietnam, Ethiopia, Germany, Egypt, Turkey, Iran, the Democratic Republic of Congo, Thailand. ${ }^{41}$ Aside from the ambiguous case of the United States, only one state embodying European-style liberalism-Germany-makes it on the list, and only in the second half of it. Most of the states-China, Pakistan, Bangladesh, Nigeria, Russia, Vietnam, Ethiopia, Egypt, Iran, and Congo-are not liberal at all. ${ }^{42}$ Iran is an authoritarian theocracy. China, Vietnam, and Russia are also authoritarian regimes.

Only a person who identifies European norms with world norms could say that the United States' wavering commitment to liberalism-if that is the case-explains its exceptionalism. This mistake-the confusion of European norms and universal international norms-is central to the claim of American exceptionalism. On this view, European norms reflect the universal norms of international law. We have not seen a defense of this view; it seems to be merely assumed. ${ }^{43}$

\section{Multiple exceptionalisms}

Against the conventional wisdom, we propose an alternative hypothesis. We argue that great powers typically support a view of international law that embodies their own normative commitments but is presented as a universal set of commitments. During the Cold War, there were two exceptional states - the United States and the Soviet Union-and each endorsed an exceptionalist, universalistic vision of international law. Today, there are three exceptional states - the United States, the EU, ${ }^{44}$ and China-and each advances a distinctive vision of international law:

41. Central Intelligence Agency, The World Factbook: Country Comparison: Population, available at https:/ /www.cia.gov/library/publications/the-world-factbook/rankorder/2119rank.html (last visited Nov. 6, 2010).

42. They are all classified as not free or partly free in Freedom House's 2010 survey. See Freedom House, Freedom in the World 2010: Global Data, available at http://www.freedomhouse.org/uploads/fiw10/ FIW_2010_Tables_and_Graphs.pdf (last visited Nov. 6, 2010).

43. See, e.g., Ignatieff, supra note 2; Rubenfeld, supra note 9 (describing European "universalism"). Rubenfeld emphasizes Europeans' faith in "international consensus" as a source of legal validation and authority. See id. at 2005-06. He also explains how Europeans are committed to the "universalistic view" of constitutional law and international human rights law, favoring "supranational legal and political institutions because most important legal and political principles . . . transcend national boundaries and indeed exist to check national governments." See id. at 1975-76. Peters, supra note 2, at 605, describes American exceptionalism against a background of global constitutional values that look suspiciously European. See also Jurgen Habermas, The Divided West 179-84 (2006) (describing Europeans' continuing commitment to the Kantian cosmopolitan order and contrasting that with American preference for hegemonic liberalism post 9/11); Martti Koskenniemi, International Law in Europe: Between Tradition and Renewal, 16 Eur. J. INT'L L. 113, 117 (2005) ("We Europeans share this intuition: the international world will be how we are. And we read international law in the image of our domestic legalism .....").

44. The EU is not technically a state and would better be described a quasi-state. However, we will refer to it as a state for simplicity's sake. 
American exceptionalism. The United States believes that international law should promote free markets and liberal democracy. Military force may be used by any country against threats to this order.

European exceptionalism. Europeans believe that international law should advance human rights (including positive or economic rights) and social welfare. Europeans reject the unilateral use of military force. Instead of resorting to military force, states should pool their sovereignty in international institutions that can resolve disputes.

Chinese exceptionalism. China takes the strictest line on sovereignty and contests the use of military force against independent states. China also believes that international law should impose less burdensome obligations on poor countries. According to China, economic growth should take precedence over human rights (at least, in poor countries).

The core of international law consists of the overlapping claims of these three states. "Unexceptional" or normal countries usually do not bother to advance distinctive visions of international law because they do not have the power to affect the development of international law. These states mostly take the law as given and try to modify it along the margins to suit their interests. There are some exceptions. In the nineteenth century, the United States, while it was still weak, advanced a distinctive view of international law, which may have influenced the development of international law. ${ }^{45}$ More often, weaker countries form blocs that advance a particular vision of international law. For instance, the non-aligned bloc that was active during the Cold War has fallen in line behind China, which by virtue of its power and size, is the natural leader of poorer countries. ${ }^{46}$ Brazil has emerged as the leader of the G20, a coalition of the developing countries in the WTO, which advances the developing country stance in the WTO negotiations with notable collective clout. ${ }^{47}$ In addition, exceptional states often try to persuade normal states to sign on to their particular exceptionalist view. The United States championed the negative rights embedded in the ICCPR and the former Soviet Union championed the positive rights embedded in the International Covenant on Economic, Social, and Cultural Rights ("ICESCR"); both examples reveal two exceptional states trying to convince normal states to adopt their respective worldviews. ${ }^{48}$ Similarly, the EU often requires normal states to subscribe to the EU's vision of international law as a condition for signing a trade agreement or acceding to the EU. ${ }^{49}$

45. See Oppenheim, supra note 16 , at 49 .

46. See Peter Wonacott \& Neil King Jr., Lowering the Wall: China Irks U.S. as It Uses Trade to Embellish Newfound Clout, Wall St. J., Oct. 3, 2005 (describing China's increased economic power in Asia, including dramatically greater clout among non-aligned countries).

47. See Much Wind and Little Light, Economist (U.S.), Oct. 18, 2003 (reporting the U.S. Trade Representative describing Brazil as the leader of the bloc of developing countries in WTO negotiations).

48. See Micheline R. Ishay, The History of Human Rights 221-29 (2004).

49. Magdalena Lièková, European Exceptionalism in International Law, 19 Eur. J. INT'L L. 463, 472-74 (2008). 
In the remainder of this paper, we will flesh out these arguments. For each state, we will (1) describe its distinctive international legal vision; (2) explain the source of this vision in domestic public opinion and institutional structure; and (3) show that these states are exceptional in the same way that the United States is exceptional.

\section{European Exceptionalism: The Pacifist Social Welfare Model}

\section{A. European exceptionalism defined}

\section{Human rights}

The EU maintains a strong commitment to international human rights. Because all EU members have ratified all of the major international human rights treaties, one might think that the EU's position on human rights reflects universal values. However, the EU's position is distinctive. The EU has its own Charter of Fundamental Human Rights, which in turn reflects in part human rights norms developed by the European Court of Justice ("ECJ"). These norms are, in fact, broader than those embodied in international treaties; they also vary in some respects from the norms advanced by the other major states.

The most distinctive human rights commitment of the EU is its opposition to capital punishment. ${ }^{50}$ The EU has sponsored multiple resolutions at the U.N. Commission on Human Rights ${ }^{51}$ and at the U.N. General Assembly, ${ }^{52}$ calling for a moratorium or outright abolition of capital punishment. The EU also discourages the death penalty through its bilateral relations: it has criticized the United States for including reservations in international human rights treaties to preserve the death penalty ${ }^{53}$ and filed amicus curiae briefs in cases where the U.S. Supreme Court has considered the suitability

50. Article 2 of the EU Charter of Fundamental Human Rights provides, "Everyone has the right to life" and "No one shall be condemned to the death penalty, or executed." Charter of Fundamental Rights of the European Union, 2000 O.J. (C 364) 1. All EU member states have signed the 13th Protocol of the 2003 European Convention of Human Rights ("ECHR"), which commits the signatories to the permanent abolition of the death penalty in all circumstances.

51. See, e.g., U.N. Economic and Social Council, Comm'n on Human Rights, 56th Sess., 66th mtg. at ๆ $17-19$, U.N. Doc. E/CN.4/2000/SR.66 (Dec. 21, 2000), available at http://daccess-dds-ny.un.org/ doc/UNDOC/GEN/G00/136/03/PDF/G0013603.pdf; U.N. Economic and Social Council, Comm'n on Human Rights, 55th Sess., 58th mtg. at I 9 38-44, U.N. Doc. E/CN.4/1999/SR.58 (July 13, 1999), available at http://daccess-dds-ny.un.org/doc/UNDOC/GEN/G99/132/70/PDF/G9913270.pdf.

52. See, e.g., Memorandum by the European Union at the 54th United Nations General Assembly 10 (Sept. 21, 1999), available at http://www.consilium.europa.eu/uedocs/cmsUpload/memo_en_99.pdf; European Union, EU Welcomes UN Vote Calling for a Global Moratorium on the Death Penalty, EU/NR 118/ 07 (Nov. 16, 2007), available at http://www.eurunion.org/eu/index.php?option=com_content\&task= view $\&$ id $=91 \&$ Itemid $=58$.

53. See Press Release, European Union, EU Demarche on the Death Penalty, Presented to the US Administration on May 10, 2001, available at http://www.eurunion.org/eu/index.php?option=com_ content\&task $=$ view\&id $=1959 \&$ Itemid $=26$. 
of capital punishment for juvenile or mentally retarded criminal offenders. ${ }^{54}$ The EU has further required the United States to sign a treaty guaranteeing that it will not seek the death penalty in murder cases that involve a request for extradition from an EU member state. ${ }^{55}$

But not all of the EU's positions on human rights are so broad. The American commitment to freedom of speech and political association is stronger than the European view. European human rights norms do not prohibit the suppression of parties and certain types of derogatory speech protected by the First Amendment to the U.S. Constitution. Some American criminal law protections (such as the exclusionary rule ${ }^{56}$ ) have no counterpart in European courts. As we will discuss later, China endorses a much stronger right to development than the EU does. On China's view, poor countries may abrogate other rights for the sake of alleviating poverty and maintaining order; the EU does not believe that the right to development can trump civil and political rights. While Europeans would argue that China is simply giving less weight to those other rights than it should, a more accurate description is that there is disagreement as to the relative weights of the right to development and other rights when they conflict.

At times the EU's commitment to human rights conflicts with its international law obligations. In 2001, the Al Qaeda and Taliban Sanctions Committee, an organ of the Security Council, placed the Saudi businessman Yassin Abdullah Kadi on a list of individuals associated with Al Qaeda. ${ }^{57}$ Under the Security Council resolution that established the Sanctions Committee in 1999, all states have a legal obligation to freeze the assets of the individuals on the Sanctions Committee's list, including Kadi. ${ }^{58}$ The EU adopted a regulation to implement the U.N. resolutions that called for the freezing of terrorist funds, including those of Kadi. ${ }^{59}$ Kadi subsequently

54. European Comm'n, Background: EU Policy against the Death Penalty 2 (Sept. 2008), available at http://www.eurunion.org/DPBackground-9-08.doc; see, e.g., Brief for the European Union and Members of the International Community as Amici Curiae Supporting Petitioner, Medellin v. Texas, 552 U.S. 331 (2008) (No. 08-5573), 2007 WL 1874804; Brief for the European Union and Members of the International Community as Amici Curiae Supporting Petitioner, Maharaj v. McDonough, 549 U.S. 1072 (2006) (No. 05-1555), 2006 WL 1594034; Brief for the European Union and Members of the International Community as Amici Curiae Supporting Petitioner, Sanchez-Llamas v. Oregon, 548 U.S. 331 (2006) (Nos. 04-10566, 05-51), 2005 WL 3530558.

55. John R. Schmidt, The EU Campaign against the Death Penalty, 49 Survival, no. 4 123, 127 (2007): see also Peter Finn, Germany Reluctant to Aid Prosecution of Moussaoui, WAsh. Post, June 11, 2002, at A1 (reporting on Germany's threat to withhold evidence if the accused, Moussaoui, may be punished with the death penalty).

56. The exclusionary rule prevents the state from using illegally obtained evidence in criminal or quasi-criminal proceedings when reliance on such evidence would effectively violate individuals' right to be protected against unreasonable searches and seizures guaranteed by the Fourth Amendment of the U.S. Constitution. See Herring v. U.S., 129 S. Ct. 695, 699-704 (2009).

57. Joined Cases C-402/05 P and C-415/05 P, Kadi v. Council of the EU, 2008 E.C.R. I-06351 I 32, available at http://eur-lex.europa.eu/LexUriServ/LexUriServ.do?uri=CELEX:62005J0402:EN:HTML [hereinafter "Kadi"].

58. See S.C. Res. 1267, I 4, U.N. Doc. S/RES/1267 (Oct. 15, 1999); see generally Kadi, supra note 57.

59. Council Regulation 881/2002, 2002 O.J. (L 139) 9 (EC). 
challenged this regulation before the ECJ. In 2008, the ECJ ruled that the Sanctions Committee's designation of Kadi did not bind the EU's member states. ${ }^{60}$ According to the ECJ, the process established by the Sanctions Committee offended fundamental human rights norms under European law because Kadi did not have an adequate opportunity to challenge the placing of his name on the Committee's list. ${ }^{61}$ Accordingly, European countries could not freeze Kadi's assets without violating Kadi's due process rights and, consequently, European law. To all appearances, the ECJ's judgment was accepted by European governments.

The ECJ's judgment indirectly challenged provisions of international law aimed against a major problem of international security and undermined the authority of the Security Council. Declaring that "the obligations imposed by an international agreement cannot have the effect of prejudicing the constitutional principles of the EC Treaty," 62 the ECJ elevated the human rights guarantees enshrined in EC treaties and general principles of European law above the U.N.-generated norms to fight terrorism. ${ }^{63}$ This was perceived as a departure from the EU's customary role as a staunch supporter of international law and the integrity of the United Nations. ${ }^{64}$

\section{Social welfare}

The EU has sought to maintain a high level of what it calls "social protection," sometimes at the expense of its international law obligations. ${ }^{65}$ For instance, the EU insists on its right to keep foreign products out of its market on grounds of food safety and other health policy concerns, precaution in the field of biotechnology, cultural diversity, and other social welfare rights, even when doing so violates EU's obligations under international trade law. ${ }^{66}$

The EU's pursuit of social policies that conflict with trade liberalization has led to challenges in the WTO. Most prominently, the EU's social wel-

60. See generally Kadi, supra note 57.

61. Id. at I $321-28$.

62. $I d$. at 9285 .

63. See id. The ECJ added that even though the EU constitutional norms and the U.N. Charter exist on a separate plane (consistent with the dualist view of international law), if they were to be classified within the same hierarchy of norms within the EU's legal order, the U.N. Charter would be subordinate to the EC Treaties and the general principles of law. See id. at $\mid$ I 305-08.

64. Gráinne de Búrca, The European Court of Justice and the International Legal Order after Kadi, 51 Harv. Int'L L.J. 1, 4-5 (2010); see also Joined Cases C-402/05 P and C-415/05 P, Kadi v. Council of the EU, Opinion of Advocate General Poiares Maduro, at I 38 (Jan. 16, 2008), available at http://curia. europa.eu/en/content/juris/c2_juris.htm (follow "C-402/05 P" hyperlink; then follow "C-402/05 P" hyperlink next to "Opinion").

65. The European Commission coordinates various "social protection" and social inclusion initiatives that, among other things, combat poverty, reform welfare systems, and provide support for problems caused by demographic changes. See European Comm'n, Social Protection E Social Inclusion, http://ec. europa.eu/social/main.jsp?catId=750\&langId=en (last visited Nov. 6, 2010).

66. Sophie Meunier \& Kalypso Nicolaïdis, The European Union as a Conflicted Trade Power, $13 \mathrm{~J}$. EuR. Pub. Pol'y 906, 921-22 (2006). 
fare objectives clashed with its WTO obligations when the EU sought to prohibit the importation of hormone-treated beef into the EU. Following a complaint from the United States, the WTO Dispute Settlement Body ruled that the EU's ban was not based on scientific evidence, and hence not justified under the relevant WTO rules. ${ }^{67}$ Similarly, the EU sought to restrict U.S., Argentine, and Canadian imports of agricultural and food products that contained genetically modified organisms ("GMOs"). The WTO Dispute Settlement Panel found the EU's restrictions were contrary to its obligations under the WTO. ${ }^{68}$ Despite these rulings against the EU, the EU has remained reluctant to modify its domestic policies, preferring to violate international trade law and endure WTO-authorized trade sanctions.

Trade conditionality offers an effective instrument for the EU to export its social welfare model abroad. ${ }^{69}$ In derogation from the principle of mostfavored-nation (non-discrimination among trading partners), the WTO allows developed countries to set up preferential tariff schedules to developing countries under the Generalized System of Preferences ("GSP").70 The EU uses its GSP system to foster its preferred social policies in the beneficiary countries: it rewards countries that ratify the main international conventions on human rights, labor standards, and sustainable development and punishes countries that do not. ${ }^{71}$ For instance, in 1997 the EU withdrew Myanmar's GSP privileges because of Myanmar's forced labor practices. Similarly, Belarus lost its GSP status in 2007 for persistent violations of labor rights, including rights to organize and to engage in collective bargaining. ${ }^{72}$ The United States similarly uses the GSP scheme to advance its distinctive view of international law. Thus, resorting to trade conditionality as an instrument to advance one's exceptionalist agenda is not a prerogative of a single state-yet the set of values that the GSP scheme is used to promote differs depending on the identity of the exceptionalist state that extends conditional preferences to its trade partners.

67. Appellate Body Report, European Communities_Measures Concerning Meat and Meat Products (Hormones), WT/DS26/AB/R, WT/DS48/AB/R (Jan. 16, 1998).

68. Panel Report, European Communities-Measures Affecting the Approval and Marketing of Biotech Products, WT/DS291/R, WT/DS292/R, WT/DS293/R, at Part VIII, §§ 8.14, 8.18, 8.34, 8.38 (Sept. 29, 2006).

69. Meunier \& Nicolaïdis, supra note 66, at 913.

70. Jan Vanderberghe, On Carrots and Sticks: The Social Dimension of EU Trade Policy, 13 Eur. ForeIGN Aff. Rev. 561, 569-70 (2008).

71. Id. at 570 .

72. Id. (citing European Comm'n, Promoting core labour standards: Commission grants additional tariff preferences to Sri Lanka and initiates an inquiry into labour rights violations in Belarus (Jan. 7, 2004), available at http://trade.ec.europa.eu/doclib/docs/2004/january/tradoc_115531.pdf); Council Regulation (EC) No 552/1997 of 24 March 1997 Temporarily Withdrawing Access to Generalized Tariff Preference from the Union of Myanmar; Council Regulation (EC) No 1933/2006 of 21 December 2006 Temporarily Withdrawing Access to the Generalised Tariff Preferences from the Republic of Belarus. 


\section{Pooling sovereignty}

The EU sees itself as the "frontrunner" and the "driving force" behind international institutions. ${ }^{73}$ The countries that would later form or join the EU (aside from Germany and other members of the defeated Axis) played an essential role in establishing the post-World War II institutions, including the United Nations, the WTO and the Bretton Woods institutions. The EU itself is the outcome of sovereignty-sharing among its twenty-seven members. While the EU does not have a common police force to enforce its law, its member states have submitted to authentic legislative, judicial, and executive institutions that issue legally binding orders that are routinely obeyed. A trope of EU public relations is that if historic enemies on the European continent can pool sovereignty, then so can countries throughout the world.

The Europeans also pooled their sovereignty by establishing a Council of Europe whose membership extends to forty-seven countries and thus beyond the member states of the EU. ${ }^{74}$ The Council of Europe seeks to advance democratic principles and human rights throughout Europe based on the European Convention on Human Rights ("ECHR"). ${ }^{75}$ The Council of Europe also established a European Court of Human Rights vested with jurisdiction to hear allegations of violations of the ECHR. Similarly, the EU has participated enthusiastically in the U.N. human rights committees, forums, and conferences, ${ }^{76}$ and has pursued numerous initiatives in the context of the U.N. Commission on Human Rights.

The EU was also a prime supporter of the ICC. All twenty-seven members of the EU have joined the ICC, including those states that needed to amend their constitutions in order to do so. ${ }^{77}$ The Rome Statute is among

73. European Comm'n, Communication from the Commission to the Council and the European ParliamentThe European Union and the United Nations: The choice of multilateralism, at \$1.1, COM (2003) 526 final (Sept. 10, 2003), available at http://eurlex.europa.eu/smartapi/cgi/sga_doc?smartapi!celexplus!prod!Doc Number\&lg $=$ en\&type_doc $=$ COMfinal\&an_doc $=2003 \&$ nu_doc $=526$.

74. Council of Europe, Council of Europe in Brief: Who We Are, available at http://www.coe.int/about coe/index.asp?page $=$ quisommesnous\&l $=$ en (last visited Nov. 6, 2010). The Council of Europe is distinct from the European Council. The Council of Europe promotes democracy and human rights among its forty-seven member states, while the European Council is a decision making body in the European Union ("EU"), consisting of the heads of all EU member states.

75. See Convention for the Protection of Human Rights and Fundamental Freedoms, Nov. 4, 1950, 213 U.N.T.S. 222, 224, available at http://www.echr.coe.int/nr/rdonlyres/d5cc24a7-dc13-4318-b4575c9014916d7a/0/englishanglais.pdf. The rights and freedoms secured by the ECHR include, for example, the right to life (abolishment of death penalty), the right to a fair hearing, the right to privacy, freedom of expression, freedom of thought, conscience, and religion, and the protection of property. The ECHR prohibits, for example, torture and inhuman or degrading treatment or punishment, forced labor, arbitrary and unlawful detention, and discrimination in the enjoyment of the rights and freedoms secured by the Convention.

76. These forums and conferences include, for instance, the U.N. Commission on Human Rights, the Third Committee of the General Assembly, the Commission on the Situation of Women, the World Conference against Racism of 2001, and the U.N. General Assembly Special Session on Children of 2002. The EU is also active in supporting the High Commissioner for Human Rights. See European Comm'n, supra note $73, \S 1.1$.

77. Int'l Criminal Court, The States Parties to the Rome Statute, http://www.icccpi.int/Menus/ASP/ states + parties/ (last visited Nov. 6, 2010); see Jeremy Rabkin, Is EU Policy Eroding the Sovereignty of Non- 
the numerous multilateral treaties that the EU requires states to sign as a condition for acceding to the EU. ${ }^{78}$ The EU also encourages ratification of the Rome Statute outside of its immediate sphere of influence through accession, including sponsoring annual U.N. resolutions supporting the ICC. ${ }^{79}$

\section{Presumptive pacifism}

The EU is skeptical about the use of military force. It sees itself as a "soft," "moral," or "normative" power that relies on its influence rather than force in maintaining world peace. ${ }^{80}$ European security strategy therefore calls for preventive efforts - including the spreading of democratic ideals, human rights, and reduction of poverty-as means to peace and security. ${ }^{81}$ The European Commission describes "the distinctive European approach" to international peace and security as follows:

[The EU has] worked to build human security, by reducing poverty and inequality, promoting good governance and human rights, assisting development, and addressing the root causes of conflict and insecurity. The EU remains the biggest donor to countries in need. Long-term engagement is required for lasting stabilisation. . . . These achievements are the results of a distinctive European approach to foreign and security policy. ${ }^{82}$

The core of the European Security Strategy is that military force should only be used as a last resort after all diplomatic means have been exhausted. The

Member States?, 1 CHI. J. INT'L L. 273, 278 (2000) (noting that Germany and France amended their constitutions to adhere to the Rome Statute).

78. See European Council, The European Union and the International Criminal Court, at 9 (Feb. 2008), available at http://www.consilium.europa.eu/uedocs/cmsUpload/ICC_internet08.pdf (explaining that "[a]chieving the widest participation in the Rome Statute was also an EU objective during the enlargement negotiations and accession phases of the new EU Member States"); see, e.g., id. at 10-11 (lauding Croatia's support for the ICC and highlighting the EU's commitment to furthering universal acceptance of the ICC); cf. Council Common Position on the International Criminal Court (EU) No. 444/2003 of 16 June 2003, 2003 O.J. (L 150) 67-68.

79. See European Council, supra note 78, at 15-16; U.N. GAOR, 63rd Sess., 45th plen. mtg. at 10, U.N. Doc. A/63/PV. 45 (Nov. 11, 2008); U.N. GAOR, 62nd Sess., 57th plen. mtg. at 27, U.N. Doc. A/ 62/PV.57 (Nov. 26, 2007); U.N. GAOR, 61st Sess., 56th plen. mtg. at 1, U.N. Doc. A/61/PV.56 (Nov. 20, 2006); U.N. GAOR, 60th Sess., 53rd plen. mtg. at 9, U.N. Doc. A/60/PV.53 (Nov. 23, 2005).

80. See Laeken Declaration on the Future of the European Union (EU) SN 273/01 of 15 Dec. 2001 ("[The EU is] a power wanting to change the course of world affairs in such a way as to benefit not just the rich countries but also the poorest. A power seeking to set globalisation within a moral framework, in other words to anchor it in solidarity and sustainable development."). See generally Ian Manners, Normative Power Europe: A Contradiction in Terms?, 40 J. Cоммоn Мкт. SтUd. 235 (2002).

81. See European Council, Report on the Implementation of the European Security Strategy, at 4, 9, S407/08 (Dec. 11, 2008), available at http://www.consilium.europa.eu/ueDocs/cms_Data/docs/pressdata/EN/ reports/104630.pdf; European Council, A Secure Europe in a Better World: European Security Strategy, at 6, 10 (Dec. 12, 2003), available at http://www.consilium.europa.eu/uedocs/cmsUpload/78367.pdf. An example of this strategy is the EU's Everything But Arms initiative, which grants duty-free and quota-free access to all exports, excluding arms and munitions, from the least developed countries. See Council Regulation 416/2001, 2001 O.J. (L 60) 43 (EC); Meunier \& Nicolaïdis, supra note 66, at 917.

82. European Council, Report on the Implementation of the European Security Strategy, supra note 81, at 2. 
EU also rejects the preventive war doctrine, and insists that Security Council authorization must be secured before force is deployed. ${ }^{83}$

Despite the pacifist rhetoric, individual EU member states have engaged in military operations in recent years-for example, in the war in Afghanistan, which was authorized by the Security Council. EU members have even used military force without international legal justification. The U.S.-led invasion of Iraq in 2003 violated international law because it did not serve any country's defensive purposes, and it was not authorized by the Security Council. ${ }^{84}$ Although France and Germany opposed the invasion, the United Kingdom, Italy, Denmark, the Netherlands, Portugal, and Spain (in addition to a number of European countries that acceded to the EU the year following the Iraq invasion) contributed troops to the mission. In 1999, all of the European members of NATO, plus France, went to war against Serbia, again under the leadership of the United States. The intervention violated international law: it was not a war of self-defense, and it lacked Security Council authorization. NATO characterized the military operation as a humanitarian intervention that was designed to stop the ethnic cleansing that Serbs orchestrated against Albanians in Kosovo. ${ }^{85}$ The military alliance stepped in when an individual state (Serbia) — and subsequently the Security Council-failed to discharge its responsibilities to protect individuals amid an exceptionally grave, unfolding humanitarian catastrophe. ${ }^{86}$

There are two important observations here. First, the European view on the legality of the use of force is distinctive. The dominant view among the European countries is that military force should be used only as a last resort, ideally (although not necessarily) with Security Council authorization, and in the service of humanitarian ideals - a point emphasized by Tony Blair in justifying British participation in the Iraq War, and made more generally during the Kosovo intervention. The U.S. and Chinese views, as we will see, differ. Second, the EU has been willing to assert aggressive interpretations of international law in order to justify its position. Thus, the idea that "hu-

83. See European Council, A Secure Europe in a Better World: European Security Strategy, supra note 81, at 1, 9 (recognizing the United States' "dominant position as a military actor" but stating that "no single country is able to tackle today's complex problems on its own" and that "[t] Council has the primary responsibility for the maintenance of international peace and security"); see also European Council, Extraordinary European Council, Brussels, 17 February 2003, at 1, 6466/03, available at http://www.consilium.europa.eu/ueDocs/cms_Data/docs/pressData/en/ec/74554.pdf (stating that "[fforce should be used only as a last resort" in resolving the crisis over Iraq's compliance with Security Council resolutions).

84. See, e.g., Thomas M. Franck, What Happens Now? The United Nations After Iraq, 97 AM. J. INT'L L. 607, 610-17 (2003) (arguing that the 2003 invasion of Iraq violated international law and the U.N. Charter).

85. Press Conference, Javier Solana, Secretary General of NATO, Wesley Clark, Supreme Allied Commander Europe of NATO (Mar. 25, 1999), available at http://www.nato.int/kosovo/press/p990325a.htm. Solana justified the bombing as necessary to "stop further humanitarian catastrophe."

86. Int'l Comm. on Intervention and State Sovereignty, Responsibility to Protect xi-xiii (Dec. 2001), available at http://www.iciss.ca/pdf/Commission-Report.pdf (giving a synopsis of the principles of R2P and the guidelines for determining whether military intervention is justified). 
manitarian intervention" could be legally justified even without Security Council authorization emerged during the Kosovo intervention.

\section{B. Explaining European exceptionalism}

\section{Domestic policy preferences: social welfare, human rights, and pacifism}

Domestic policy preferences emphasizing the importance of social welfare explain the distinctive vision of international law that Europe advances. European public opinion supports the "social market economy," a compromise between socialism and laissez-faire capitalism that features a generous safety net, some industrial policy, strong unions, and more intrusive market regulation than one finds in the United States. ${ }^{87}$ Of course, the United States and every other developed country similarly supply a minimum safety net and regulate the market. But the faith in the role of the government as the provider of social welfare is a more central part of the European identity than it is in most other Western countries.

This commitment to welfare state and government regulation is reflected in the EU's trade policy. Although critics allege that the EU's breach of WTO rules in the cases of beef hormones and GMOs reflect protectionism ${ }^{88}$ - and without doubt the European producers of hormone- and GMOfree products benefit from the EU's insistence that free trade must occasionally yield to health concerns ${ }^{89}$ - the EU has asserted that it is merely responding to European consumers' concerns about food safety. Public sentiment within the EU is skeptical of GMOs and hormones in food. A 2006 survey of European consumers revealed that sixty-two percent of respondents across the EU were "worried" about the food safety risks posed by GMOs. ${ }^{90}$ A similar opinion poll from 2001 showed that seventy-one percent

87. This is often referred to as an "embedded liberalism" compromise. See John G. Ruggie, International Regimes, Transactions, and Change: Embedded Liberalism in the Postwar Economic Order, 36 INT'L ORG. 379, 392-98 (1982); see generally Gøsta Esping-Andersen, The Three Worlds of Welfare CapitalISM (1990).

88. See, e.g., Panel Report, supra note 68, at $\$ \S 4.152-53,4.173-4.180$ (outlining the U.S. argument before the WTO, which contrasted the EU's purported purpose of maintaining food safety with the discriminatory effects of the food safety regulations); Benedetto Della Vedova, Op-Ed., Bio-Fueling a Trade War, WALL ST. J., Aug. 3, 2009, available at http://online.wsj.com/article/SB1000142405297020 4313604574328533995657764.html (giving one former European Parliament member's opinion that the EU uses environmental protections to disguise protectionism).

89. European cattle farmers do not use hormones in raising cattle, whereas U.S. beef producers give hormones to ninety percent of their cattle. See Frode Alfnes \& Kyrre Rickertsen, European Consumers' Acceptance of US Hormone-Treated Beef, 3(3) EuroChoices 18 (Nov. 2004). Similarly, by restricting the importation of GMO-products to Europe, the EU's measures adversely affect the United States, Argentina, Brazil, and Canada, which cultivate ninety percent of the GMOs and food containing GMOs worldwide. Press Release, European Comm'n, Europe's rules on GMOs and the WTO (Feb. 7, 2006), available at http://europa.eu/rapid/pressReleasesAction.do? reference $=\mathrm{MEMO} / 06 / 61 \&$ format $=\mathrm{PDF} \&$ aged $=1 \&$ lan guage $=$ en\&guiLanguage=en; see also WTO panel rules EU GMO moratorium illegal (Feb. 8, 2006), http:// www.euractiv.com/en/trade/wto-panel-rules-eu-gmo-moratorium-illegal/article-152341.

90. European Comm'n, Special Eurobarometer 238: Risk. Issues, at 53 (Feb. 2006), available at http://ec. europa.eu/public_opinion/archives/ebs/ebs_238_en.pdf. 
of Europeans do not want GMOs in their food. ${ }^{91}$ Regarding hormones, a 1998 Eurobarometer survey shows that fifty-four percent of those surveyed indicated it important for food safety that food was " $100 \%$ free from hormones." 92 These surveys show that the import-competing industries are not alone in urging the EU to violate WTO law when social policy considerations so warrant.

Europe's recent history of wars and violence stands prominently among the reasons behind the EU's human rights advocacy and presumptive pacifism. The extreme nationalism and the brutality of two World Wars implanted revulsion for war and engrained the ideals of human dignity and pacifism deep within the European mindset. The legacy of wars and violence has heightened the EU's concern for human rights. For instance, large-scale state-sanctioned violence that the Europeans endured partly explains why opposition to the death penalty is the paramount concern in the EU's external human rights policy. ${ }^{93}$

These experiences have also caused the EU to largely refrain from using military force and pursue peaceful means to solve international disputes. The EU has not established a European army. Rather, it considers itself a "civilian power" that pre-empts military conflicts through institutional engagement and diplomacy. This explains why most EU countries did not share U.S. concerns about joining the ICC: states that are frequently engaged in military operations abroad are aware that their soldiers might one day be forced to stand a trial before the ICC. This threat was not significant for most EU states, which are rarely involved in international military conflicts. ${ }^{94}$ Only Britain and France, both with extensive military capacities, initially expressed reservations about the ICC but ultimately assented to the other EU members' joint position in the end. ${ }^{95}$

This explanation of the presumptive pacifism of Europe should not, however, be taken too far. Britain and France used considerable violence to prevent the loss of their colonies after World War II. Britain fought a war in Malaysia. France fought wars in Indochina and North Africa. Both countries

91. European Comm'n, Eurobarometer 55.2: Europeans, Science, and Technology, at 40 (Dec. 2001), available at http://ec.europa.eu/research/press/2001/pr0612en-report.pdf.

92. European Comm'n, Eurobarometre 49: La Securite des Produits Alimentaires, at 15 (Sept. 3, 1998), available at http://ec.europa.eu/dgs/health_consumer/library/surveys/eb49_fr.pdf; see also Jayson L. Lusk et al., Demand for Beef from Cattle Administered Growth Hormones or Fed Genetically Modified Corn: A Comparison of Consumers in France, Germany, the United Kingdom, and the United States, 85 Am. J. Agric. Econ. 16, 23 (Feb. 2003) (reporting that, on a scale of one (not concerned) to five (very concerned), French, German, and U.K. consumers reported average levels of concern of 4.54, 4.38 and 4.20, respectively, regarding the use of hormones in livestock production).

93. See Carol S. Steiker, Capital Punishment and American Exceptionalism, 81 OR. L. Rev. 97, 126-27 (2002) (noting that the death penalty was outlawed in several European countries in the immediate aftermath of WWII, following the wave of executions of innocent civilians without a trial); see also Schmidt, supra note 55, at 125 (noting that other European countries kept capital punishment on their books but refrained from enforcing the punishment).

94. See Rabkin, supra note 77 , at 279.

95. Id. 
participated in an ill-fated attack on Egypt in 1956. Despite the absence of a European army, all the major European countries have maintained large armies. ${ }^{96}$ They participated in the 1999 Kosovo War, the 1991 Gulf War, the war in Afghanistan, and (many of them, above all Britain) the 2003 Iraq War. European countries also did not make the promotion of democracy and human rights a priority in international relations until relatively recentlyat best, in the last two decades. ${ }^{97}$

Thus, European pacifism is as rational a response to the current global distribution of military power as it is a reflection of a European ideology. Europeans remain hostile toward unilateral use of force largely because Europeans have limited capacity to engage in unilateral military action themselves. ${ }^{98}$ Insisting on multilateralism ensures that Europeans have a vote on whether and when U.S. troops are dispatched to fight for international peace and security. The relatively benign U.S. hegemony (in European eyes) also enables Europeans to embrace pacifism: as long as the United States keeps the world peace, Europe is not required to spend money on armies and take the risks of war. ${ }^{99}$

\section{Institutional structure}

The European countries have had disproportionate influence over the creation of current multilateral institutions. The voting power in the existing institutions, including the U.N. and Bretton Woods institutions, reflects the distribution of power in the world following World War II: the EU member states hold two of the five permanent and two of the ten nonpermanent seats in the Security Council. Similarly, the EU (together with the United States) wields disproportionate influence in the IMF and the World Bank. In light of this, the EU's enthusiasm for preserving existing institutional cooperation is hardly surprising.

The EU has been successful in incorporating its vision into many multilateral arrangements, including treaties as diverse as the Agreement on Trade-Related Aspects of Intellectual Property Rights, the Landmines Treaty, the Rome Statute, and the Kyoto Protocol to the United Nations Framework Convention on Climate Change ("Kyoto Protocol”). The EU's "hybrid" institutional structure helps it shape international agreements and

96. See infra Table 1 , at note 210. It should also be noted that this is not a recent historic development, as the great powers of Europe have long maintained among the largest standing armies in the modern world. See Mearsheimer, supra note 3, at 83-137.

97. See Diego J. Liñán Nogueras \& Luis M. Hinojosa Martínez, Human Rights Conditionality in the External Trade of the European Union: Legal and Legitimacy Problems, 7 Colum. J. Eur. L. 307, 315-17 (2001) (describing the sequence of agreements made to create a policy of external promotion of human rights as beginning in the mid-1990s).

98. See Robert Kagan, Power and Weakness, 113 Pol. Rev. 3, 13-14 (2002).

99. See, e.g., id. at 8 . 
institutions toward its preferences. ${ }^{100}$ The EU often bargains as a single entity, enjoying the leverage of the biggest trading bloc in the world. ${ }^{101}$ However, when it comes time to vote, the EU casts twenty-seven votes on the matter. The EU can also refrain from making commitments, using the argument that the European Commission negotiates as a constrained agent of the member states. ${ }^{102}$ For instance, the Commission can resist demands to remove agricultural protection by saying that it cannot secure the backing of the French farmers for the proposal. Presenting the "French problem" as an "EU problem," the French farmers' demands suddenly enjoy the bargaining power of a trading bloc speaking on behalf of 500 million consumers. ${ }^{103}$ The EU may therefore be more eager to join an international agreement than other states because its bargaining tactics give its member states more power to affect the agreement's content.

The EU's own experience with integration may explain why it strongly advocates the pooling of sovereignty internationally. The long experience with integration in Europe has eroded the rhetorical power of "sovereignty" - the notion, deeply entrenched in the United States and China, that any loss of authority to supranational institutions is an intolerable affront to the dignity of a state. The EU also considers itself to be a thriving example of how international conflicts can be overcome and how countries can peacefully co-exist and prosper. As we discuss below, in comparing the EU to the United States, European countries have a less populist form of democracy than the United States does, and, as a result, lack populist skepticism of remote bureaucracies. ${ }^{104}$ European experience with fascism in World War II left the Europeans skeptical of popular democracy. An important function of international law is therefore to act as an antinationalist force by checking national sovereignty and guarding states against "democratic excess." 105 As a result, there is less popular resistance in Europe to delegation of authority to international agencies. ${ }^{106}$

100. See generally Meunier, supra note 66 (discussing how the EU is a power in trade and through trade).

101. See id. at 908-09. Currently there are 27 members in the EU: Austria, Belgium, Bulgaria, Cyprus, Czech Republic, Denmark, Estonia, Finland, France, Germany, Greece, Hungary, Ireland, Italy, Latvia, Lithuania, Luxembourg, Malta, the Netherlands, Poland, Portugal, Romania, Slovakia, Slovenia, Spain, Sweden, and the United Kingdom. European Union, Member States of the EU, http://europa.eu/abc/ european_countries/eu_members/index_en.htm (last visited Nov. 6, 2010).

102. Meunier, supra note 66, at 909. See generally Robert D. Putnam, Diplomacy and Domestic Politics: The Logic of Two-level Games, 42 INT'L ORG 427, 434 (1988) (explaining two-level bargaining when a constrained agent negotiates on behalf of a principal).

103. Rabkin, supra note 77 , at 274-75.

104. See Rubenfeld, supra note 9, at 1975 (contrasting American "democratic constitutionalism" with European "international constitutionalism").

105. Id. at 1986-87, 2006.

106. However, integration has produced a backlash. See Gráinne de Búrca, After the Referenda, 12 EUROPEAN L.J. 6 (2006) (describing the failure to ratify a European Constitution as a moment of public expression on the direction of the EU that cannot be ignored); see also Maria Cahill, Ireland's Constitutional Amendability and Europe's Constitutional Ambition: The Lisbon Referendum in Context, 9 German L.J. 1191, 1191-94 (2008) (describing how the Lisbon Treaty was rejected by popular referendum in Ireland); Eric 
Finally, the EU advocates strong multilateral institutions, in particular security institutions, because of its own limited ability to engage in unilateralism. While the EU member states have pooled their sovereignty on many issues of economic importance, the common foreign and security policy of the EU is limited. Any decision relating to security policy is subject to the requirement of unanimity among the twenty-seven member states. There is also no common European military force that can be dispatched to intervene in international conflicts. ${ }^{107}$ Insisting on obtaining Security Council authorization for the use of military force thus rarely constrains the EU's own military ambitions, yet gives its important member states, France and the United Kingdom, a right to a veto any attempt by the United States to exercise force unilaterally. Thus, as long as the EU continues to lack a strong, unified European military force, it is likely to prefer constraining other exceptionalist states' unilateralism through the disproportionate influence it wields in the Security Council.

\section{Chinese Exceptionalism: Minimalist Developmentalism}

\section{A. Chinese exceptionalism defined}

\section{Strict sovereignty}

China's vision of international law rests on the principle of sovereignty. Under the Chinese view, sovereign states have an inalienable right to exercise jurisdiction over their territories and their people without interference from other states. ${ }^{108}$ The internal affairs of a state are left for the state's own people to govern; international affairs are decided by consultation among states acting on the basis of equality and mutual benefit. ${ }^{109}$ While the inte-

Posner, Europe's Missing Identity, WALL ST. J., June 2, 2010 (describing the limits to supranational delegation of powers to international institutions in the absence of common identity).

107. The EU has deployed forces under the name of the "European Union Force" four times-to Macedonia (2003), Bosnia (2004), Congo (2006), and in Chad and the Central African Republic (2007). These deployments, however, are not from a permanent EU military, which the EU has failed to create due to internal disputes and continued reliance and deferral to NATO. See James G. McLaren, Europe's Efforts to Develop an Autonomous Defense Capability, A Constitution of Europe, and the Implications for NATO, 11 Colum. J. Eur. L. 523, 523-36, 548-56 (2005).

108. Over the years, China has continued to assert that its sovereignty extends to Taiwan, which it considers to be a province under its "one China" policy. Because of this, China has blocked Taiwan from joining the United Nations as a member and impeded Taiwan's ability to enter into relations with other states. Foreign governments' attempts to engage directly with Taiwan have provoked strong reactions in Beijing. For instance, when the United States announced its intention to sell advanced weapons to Taiwan in 2001, China protested by stating that the weapons deal would violate the Sino-U.S. open communiqué and infringe China's territorial sovereignty. See Björn Ahl, China, in Max Planck EnCyclopedia of Public International Law $\S \mathrm{C}$, available at http://www.mpepil.com/subscriber_article?script=yes \&id=/epil/entries/law-9780199231690-e1876\&recno=24\&letter $=$ c.

109. Wen Jiabao, Premier of the State Council of the People's Republic of China, Address at the Rally Commemorating the 50th Anniversary of the Five Principles of Peaceful Coexistence (June 28, 2004), in 3 ChInese J. INT'L L. 363, 365-66 (2004), available at http://www.fmprc.gov.cn/eng/topics/ seminaronfiveprinciples/t140777.htm. 
grated global economy inevitably compromises states' economic sovereignty, their military, political, and cultural sovereignty remain inviolable. ${ }^{110}$ Consequently, China rejects all perceived attempts, including criticism of its human rights policies, to undermine its sovereignty. ${ }^{111}$

China bases its vision of international law on the "Five Principles of Peaceful Coexistence," which were first established in an agreement between China and India in 1954. These principles are mutual respect for the territorial integrity and sovereignty of other states; mutual non-aggression; mutual non-interference in the internal affairs of other states; equality and mutual benefit; and peaceful coexistence. ${ }^{112}$ Since then, these principles have become a guiding doctrine of international relations for the Chinese government. ${ }^{113}$ Of these principles, the most elemental in China's view is the principle of sovereignty. ${ }^{114}$ In commemorating the 50th anniversary of the Five Principles in 2004, Chinese Premier Wen Jiabao referred to sovereignty as "the birthmark of any independent state, the crystallization of its national interests and the best safeguard of all it holds dear." 115

As a part of its efforts to promote a world order based on the principle of sovereignty, China accords strong authority to the U.N. Charter and the Security Council. ${ }^{116}$ Qian Qichen, former foreign minister of China, gave special emphasis to the United Nations' role in maintaining a pluralist world, describing the United Nations as the "most universal, representative, and authoritative international organization in the world." 117 Moreover, Qichen called on states to uphold the United Nations' authority and to acknowledge its dominant role in conducting international affairs. ${ }^{118}$

China has applied this view of international law to maintain its position that human rights concerns do not trump the principle of sovereignty. China regularly defies criticism of its human rights record by the United Nations, foreign countries and NGOs. ${ }^{119}$ It resists the Western concept of

110. Ahl, supra note 108 , § C.3.

111. See Rosemary Foot, Chinese Strategies in a US-Hegemonic Global Order: Accommodating and Hedging, 82 INT'L AFF. 77, 88 n.31 (2006).

112. Ministry of Foreign Affairs of the People's Republic of China, The Five Principles, available at http://www.fmprc.gov.cn/eng/topics/seminaronfiveprinciples/t140589.htm.

113. Xue Hanquin, Chinese Observations on International Law, 6 CHINESE J. INT'L L. 83, 86 (2007). Xue is the Chinese member of the International Law Commission.

114. Id.

115. Wen, supra note 109 , at 365 .

116. See Foot, supra note 111, at 91-92.

117. Id. at 91 .

118. Id.

119. See, e.g., Ministry of Foreign Affairs of the People's Republic of China, Statement By H.E. Ambassador Qiao Zhonghuai, Head of the Chineses [sic] Delegation, Before the Vote on the Draft Resolution Entitled "Situation of Human Rights in China" at the 56th Session of the Commission on Human Rights (April 18, 2000), available at http://www.fmprc.gov.cn/eng/wjb/zzjg/gjs/gjzzyhy/2594/2596/t1 5151.htm; U.N. Human Rights Council Fourth Universal Periodic Review, 11th Plenary Meeting Webcast (Feb. 9, 2009), available at http://www.un.org/webcast/unhrc/archive.asp?go=090209; Ariana Eunjung Cha, China Tells U.N. Panel That It Respects Rights, Wash. Post, Feb. 10, 2009, at A12; $c f$. People's Daily Online, Full Text of the Human Rights Record of the US in 2004 (Mar. 3, 2005), 
human rights as incompatible with its non-Western and non-democratic society. ${ }^{120}$ Under this view, advancement of norms relating to human rights and democratic governance presumes a hierarchy of civilizations, and leads to an imposition of one's culture and values on others.

China has also opposed U.N. human rights resolutions against other countries, fearing that such resolutions are primarily tools to exert political pressure on developing countries. ${ }^{121}$ In January 2007, for instance, China used its veto in the Security Council to block a resolution denouncing human rights violations in Myanmar. In doing so, it argued that the U.N. Charter grants the Security Council authority to intervene in the internal affairs of a state only if there is a threat to international peace and security. This criterion, according to China, was not satisfied in the case of $\mathrm{My}$ anmar. ${ }^{122}$ Similarly, China opposed a proposed Security Council resolution authorizing military intervention in Kosovo in 1998, asserting that the Kosovo matter was an internal affair of the state. ${ }^{123}$

The United States and EU have challenged China's non-intervention policy and called on China to support responsible humanitarian intervention. Recently, China has_-slowly and reluctantly_backed away from its earlier stance that state sovereignty can never be compromised on humanitarian grounds. ${ }^{124}$ Concerned over its international reputation, China reversed its position on Myanmar and supported a subsequent Security Council statement condemning Myanmar's violent suppression of peaceful demonstrators in the fall of $2007 .{ }^{125}$ China also pressed Sudan to accept the U.N. and African Union peacekeepers in Darfur. ${ }^{126}$ Still, it is unlikely that China will depart from its non-interference principle except when put under significant foreign pressure. ${ }^{127}$ China's official position on humanitarian intervention continues to be a minimalist one: intervention is justified only in response

available at http://english.peopledaily.com.cn/200503/03/eng20050303_175406.html (China's response to the United States' periodic report of the human rights record in China).

120. See Ahl, supra note 108, § C.6.

121. Zhu Lijiang, Chinese Practice in Public International Law: 2007(II), 7 CHINESe J. INT'L L. 735, 741 (2008).

122. U.N. SCOR, 62d Sess., 5619th mtg. at 3, U.N. Doc. S/PV.5619 (Jan. 12, 2007) (remarks by Wang Guangya, Chinese representative to the United Nations).

123. U.N. SCOR, 55th Sess., 3868th mtg. at 11, U.N. Doc. S/PV.3868 (Mar. 31, 1998) (remarks by Shen Guofang, Chinese representative to the United Nations).

124. See C. Fred Bergsten et al., China's Rise: Challenges and Opportunities 227-28 (2008),

125. Ministry of Foreign Affairs of the People's Republic of China, Foreign Ministry Spokesperson Liu Jianchao's Remarks on the Chairman's Statement of UN Security Council on the Myanmar Issue (Oct. 12, 2007), available at http://www.fmprc.gov.cn/eng/xwfw/s2510/2535/t371707.htm; see U.N. SCOR, 5757th mtg., U.N. Doc. S/PV.5757 (Oct. 11, 2007); see also Human Rights Council Res. S-5/1, Situation of Human Rights in Myanmar: Draft Resolution / Portugal (on Behalf of the European Union), 5th Sess., Oct. 2, 2007, U.N. GAOR, 62d Sess., A/HRC/S-5/L.1/Rev. 1, (Oct. 2, 2007).

126. See Ministry of Foreign Affairs of the People's Republic of China, Hu Jintao Meets with Sudanese First Vice President (July 19, 2007), available at http://www.fmprc.gov.cn/eng/wjb/zzjg/xybfs/xwlb/t34 3862.htm; see also Ministry of Foreign Affairs of the People's Republic of China, Yang Jiechi Welcomes UN Security Council Resolution to Send Peacekeeping Force to Darfur (Aug. 1, 2007), available at http:/ /www.fmprc.gov.cn/eng/wjb/wjbz/2467/t347715.htm.

127. See Bergsten Et AL., supra note 124, at 228. 
to a target state's request to intervene and only if U.N. authorization is first secured. ${ }^{128}$

The principle of sovereignty also dominates China's position toward the ICC. The Rome Statute grants the ICC jurisdiction to try individuals for genocide, war crimes, and crimes against humanity, provided that those individuals' own states are unwilling or unable to investigate or prosecute the case. ${ }^{129}$ This precondition, called the "complementarity principle," dissuaded China from signing the Treaty in the end, even though it participated in the treaty negotiations. ${ }^{130}$ China maintained that "jurisdictional sovereignty of states should be strengthened rather than compromised."131 China opposed the complementarity principle on the grounds that the ICC's decision to pronounce a state unable or unwilling to prosecute a case could be politically motivated. ${ }^{132}$ In refusing to expose its domestic criminal justice system to a possible review by the ICC, ${ }^{133}$ China confirmed that state sovereignty and the principle of non-interference are the key ordering principles of its vision of international law.

\section{Developmentalism}

Even with China's emphasis on the principle of sovereign equality, China does not envision that all sovereign states should have equal rights and responsibilities. Instead, the Chinese maintain that states' international obligations ought to be adjusted to their different stages of development and their unequal capacities to comply with international law. ${ }^{134}$ For the Chinese, the right to development is a fundamental principle of international law. ${ }^{135}$ Developed countries are in a better position to maintain international order. ${ }^{136}$ Consequently, they must accept more burdensome obligations in providing public goods, including a clean environment and liberal trade order. In contrast, developing countries are entitled to various exceptions that reflect their lesser abilities to assume international obligations. Accordingly, China advances a vision of international law that is grounded on the idea of fairness and redistribution.

128. Ahl, supra note 108 , § C.5.

129. The Rome Statute of the International Criminal Court arts. 5, 17, July 17, 1998, 2187 U.N.T.S. 90.

130. See Lijun Yang, On the Principle of Complementarity in the Rome Statute of the International Criminal Court, 4 Chinese J. INT'L L. 121, 130-32 (2005).

131. Xue, supra note 113 , at 92 .

132. Id. at 93 .

133. See id. at 91-92.

134. See, e.g., Zhu, supra note 121, at 754-55 (quoting a Chinese Foreign Ministry spokesperson who explains the Chinese "common but differentiated responsibilities" policy as it relates to international environmental law).

135. See Ahl, supra note 108, § C.6.

136. See, e.g., Rosemary Foot, Chinese Power and the Idea of a Responsible State, CHINA J., Jan. 2001, at 1, 12. 
This developmental perspective guides China's position on international environmental law. When negotiating states' responsibilities to reduce greenhouse gas emissions under the Kyoto Protocol, China supported the Protocol but resisted the imposition of binding obligations on developing countries. ${ }^{137}$ According to China, developed countries should bear the primary responsibility for global environmental protection due to their higher level of industrialization and, consequently, their disproportionate contribution to climate change. Developed countries also have the resources to invest in technologies that enable them to reduce environmental harm. China's position, which ultimately prevailed, reflects the principle of "common but differentiated responsibilities"- "common," because climate change entails risks that affect all states; "differentiated," to suggest that not all states have to contribute equally in reducing or eliminating those mutual risks. ${ }^{138}$ Instead, this view stresses that wealthier states should assume a greater share of the burden of fighting climate change. While promulgating its commitment to (non-binding) emission cut targets during the Copenhagen climate change negotiations in 2009, China continued to insist that developed countries must assume the leadership role in fighting climate change. ${ }^{139}$

Similarly, in the WTO, China supports the principle of special and differential treatment, which allows for various exceptions and preferences for developing countries. For instance, developing countries benefit from an "enabling clause" that permits derogations to the non-discriminatory treatment in favor of developing countries. ${ }^{140}$ The enabling clause therefore forms an exception to the principle of reciprocity, which calls for the exchange of balanced concessions among states. In practice, this means that developed countries extend preferential tariff schedules to developing countries without offering the same concessions to their other (developed country) trading partners. Nor do developing countries need to open their domestic markets to the same extent as developed countries. ${ }^{141}$ Developing countries are also eligible for transitional periods that allow them to adjust

137. See Christopher D. Stone, Common But Differentiated Responsibilities in International Law, 98 Aм. J. INT'L L. 276, 279 (2004).

138. Id. at 276-77.

139. Nat'l Dev. and Reform Comm'n of the People's Republic of China, Implementation of the Bali Roadmap: China's Position on the Copenhagen Climate Change Conference (May 20, 2009), available at http:// en.ndrc.gov.cn/newsrelease/t20090521_280382.htm.

140. "Notwithstanding the provisions of Article I of the General Agreement, contracting parties may accord differential and more favorable treatment to developing countries, without according such treatment to other contracting parties." Differential and Favourable Treatment Reciprocity and Fuller Participation of Developing Countries, L/4903 at I 1 (Nov. 28, 1979), available at http://www.wto.org/english/docs_e/ legal_e/tokyo_enabling_e.pdf (note that this document was promulgated within the WTO's predecessor framework, the GATT).

141. The preferential tariff treatment of developing countries is often administered under domestic GSP programs, which the enabling clause allows individual states to set up. The United States, for instance, provides a duty-free entry for about 4800 designated products from over 130 beneficiary countries and territories. These do not include China. See Office of the U.S. Trade Representative, Generalized System of Preference (GSP), available at http://www.ustr.gov/trade-topics/trade-development/preferenceprograms/generalized-system-preference-gsp (last visited Nov. 6, 2010); Office of the U.S. Trade Repre- 
to surges in foreign imports, and for technical assistance to help them implement new WTO commitments. ${ }^{142}$

China's approach to international human rights also follows the logic of developmentalism. According to Chinese policy, the key human right is the right to development, which trumps all others in the hierarchy of the human rights discourse. ${ }^{143}$ Civil and political rights have to yield, when necessary, to the larger goal of economic development. ${ }^{144}$ The Chinese view on human rights also emphasizes collective rights over individual rights. Human rights are not understood to be inalienable rights that precede the existence of the state. ${ }^{145}$ Rather, China emphasizes that human rights derive from the state, which can grant those rights, subject to conditions. ${ }^{146}$ Since human rights derive from the state, China argues, nations will vary in their understanding of human rights based on their national traditions and level of economic development.

China's pursuit of redistribution of power and wealth from North to South is characteristic of the developing countries' decades-strong commitment to a more equitable division of wealth. In the 1970s, developing countries advanced proposals for a New International Economic Order ("NIEO") through the United Nations. ${ }^{147}$ One product of these efforts was the adoption in 1974 of the Resolution for a Charter of Economic Rights and Duties of States by the U.N. General Assembly. ${ }^{148}$ The idea behind the NIEO and the Charter of Economic Rights and Duties was to offer an alternative to the Western-dominated Bretton Woods institutions, and revise the international economic system in favor of developing countries. Arguing that they deserved restitution for the economic and social costs of colonization, developing countries demanded trade concessions and more generous foreign aid than they had received in the past. ${ }^{149}$ They also demanded the right to expropriate foreign property without paying full compensation. ${ }^{150}$ While China was never able to claim restitution relating to colonization, it follows

sentative, Information on Countries Eligible for GSP, available at http://www.ustr.gov/sites/default/files/ ATT\%20(A)\%20-\%20090417\%20GSP_BDC.pdf (last visited Nov. 6, 2010).

142. Mitsuo Matsushita et al., The World Trade Organization: Law, Practice, and Policy 386-88 (1st ed. 2003).

143. See Zou Keyuan, China's Legal Reform: Towards the Rule of Law 244 (2006) (citing Information Office of the State Council of the PRC, Human Rights in China, Government White Paper 1 (1991)) ("the right to subsistence is the foremost human right the Chinese people long fight for [sic]").

144. Foot, supra note 111 , at 84

145. Ahl, supra note 108, § C.6.

146. Id.

147. Mitsuo Matsushita et al., supra note 142 , at 388-89.

148. G.A. Res. 3281 (XXIX), U.N. GAOR, 29th Sess., U.N. Doc. A/RES/29/3281 (Dec. 12, 1974); see also Charter of Economic Rights and Duties of States, G.A. Res. 40/182, U.N. GAOR, 119th Sess., U.N. Doc. A/RES/40/182 (Dec. 17, 1985).

149. Mitsuo Matsushita et al., supra note 143, at 388-89.

150. See Andrew T. Guzman, Why LDCs Sign Treaties That Hurt Them: Explaining the Popularity of Bilateral Investment Treaties, 38 VA. J. INT'L L. 639, 647-51 (1998) (describing developing countries' efforts to undermine the Hull Rule, which required "prompt and adequate" payment for expropriation of foreign property, in favor of an alternate international rule that allowed for self-determined payment). 
the legacy of the NIEO by holding that states should grant special treatment to developing countries in key areas of international law. ${ }^{151}$

\section{B. Explaining Chinese exceptionalism}

\section{Domestic policy preferences: economic growth and reduction of poverty}

China's staggering growth rates have transformed China from a rural undeveloped country to an economic powerhouse. ${ }^{152}$ With a GDP exceeding four trillion dollars, China has the second largest economy in the world after the United States. ${ }^{153}$ China's massive trade surplus has allowed it to accumulate over two trillion dollars in foreign exchange reserves. ${ }^{154}$ Few would question that China has emerged as an economic giant that wields significant power in the global economy.

Despite its astounding economic growth, China remains a poor country. With a GDP per capita of about $\$ 6000,{ }^{155}$ China ranks 101 st in the world. ${ }^{156}$ Lifting people out of poverty is of the utmost concern to the vast majority of the Chinese people. Acquiescence in authoritarian rule rests in part on the Chinese government's ability to pursue economic growth, alleviate poverty, and spread wealth to an increasing share of its population. China's rapid economic rise has had the downside of increasing economic inequality within China, heightening the risk of political tensions. There is ethnic and religious conflict in the western provinces, and civil unrest throughout the country. ${ }^{157}$ The Chinese government has determined that only continued high economic growth can maintain social order and political stability. ${ }^{158}$

151. See Zha Peixin, H.E. Ambassador, Ministry of Foreign Affairs of the People's Republic of China, Speech at the Chinese Economic Association Annual Conference (Apr. 14, 2003), available at http://www. fmprc.gov.cn/ce/ceuk/eng/dsjh/t27161.htm; see also Su Wei, Ministry of Foreign Affairs of the People's Republic of China, Statement by the Chinese Delegation on Agenda Item 154: The Progressive Development of International Legal Principles and Rules for a New International Economic Order (Oct. 16, 2000), available at http://www.fmprc.gov.cn/ce/ceun/eng/chinaandun/legalaffairs/sixthcommittee/t2856 0.htm.

152. Access to foreign markets has fueled China's economic growth and allowed it to sustain growth rates averaging over nine percent each year since its 2001 accession to the WTO.

153. David Barboza, China Passes Japan as Second-Largest Economy, N.Y. Times, Aug. 15, 2010, at A12.

154. Central Intelligence Agency, The World Factbook, Country Comparison: Reserves of Foreign Exchange and Gold, available at https://www.cia.gov/library/publications/the-world-factbook/rankorder/2188rank. html (last visited Nov. 6, 2010).

155. Int'l Monetary Fund, World Economic Outlook Database, http://www.imf.org/external/pubs/ft/weo/ 2009/01/weodata/weoselgr.aspx (click "all countries" hyperlink and select China; then click "select all"; then select start year "2008" and end year "2008") (last visited Nov. 6, 2010) (GDP per capita based on the current international dollar, purchasing power parity, using 2008 statistics).

156. Id. (click "all countries" hyperlink and "select all"; then select "Gross domestic product based on purchasing-power-parity (PPP) per capita GDP" and select start year "2008" and end year "2008"; download table and sort by 2008 column) (last visited Nov. 6, 2010).

157. See, e.g., Is China Fraying?, The Economist (U.S.), July 11, 2009.

158. See Yang Yao, The End of the Beijing Consensus, Foreign AfF., Feb. 2, 2010, available at http:// www.foreignaffairs.com/articles/65947/the-end-of-the-beijing-consensus ("Since the Chinese Communist 
In its quest for continuing economic growth, China pursues an export-led growth strategy and manipulates its currency so as to keep the prices of its exports artificially low. To further facilitate its trade, China acceded to the WTO, taking advantage of the special and differential treatment available for developing countries. ${ }^{159}$ Special and differential treatment allows developing countries to benefit from longer time periods for implementing WTO commitments. ${ }^{160}$ These provisions also allow developed countries to increase trading opportunities for developing countries without offering comparable opportunities for other WTO member states.

China has also insisted on special and differential treatment in global climate change negotiations. In 2006, China passed the United States as the largest emitter of greenhouse gases in the world, and China's emissions continue to grow at a very high rate. ${ }^{161}$ China's high rate of emissions is the result of its booming economy and consequent high use of energy in manufacturing. China's comparative advantage in international manufacturing is partly based on low energy costs as a consequence of its large coal reserves. Thus, China has weak incentives to switch to alternative fuel sources or to sign any international treaty that would force it to do so.

To resist demands for significant cuts in its emissions, China has advocated a developmentalist response to climate change. It has proposed using countries' historical emissions as a benchmark for assigning emission reduction targets among states. ${ }^{162}$ Over the course of the history of industrialization, most emissions originated from developed countries when they were pursuing greater levels of development; this is akin to what China is currently doing. Alternatively, China has suggested that per capita emissions should form a baseline for contemplated emission reductions. ${ }^{163}$ Using per capita emissions as a benchmark for the state's global responsibility would have a very different impact on China's responsibilities than any metric fo-

Party (CCP) lacks legitimacy in the classic democratic sense, it has been forced to seek performance-based legitimacy instead, by continuously improving the living standards of Chinese citizens.").

159. WTO rules do not contain a definition of a "developing country." Instead, states self-designate themselves as developed or developing countries as part of a political calculus. The United States and the EU persistently opposed China's attempts to claim developing country status based on the size of its economy and trade flows.

160. See WTO Committee on Trade and Development, Implementation of Special and Differential Treatment Provisions in WTO Agreements and Decisions, WT/COMTD/W/77/Rev.1, at 8 (Sept. 21, 2001).

161. Michael P. Vandenbergh, Climate Change: The China Problem, 81 S. Cal. L. Rev. 905, 914 (2007-08).

162. See Eric Neumayer, In Defense of Historical Accountability for Greenhouse Gas Emissions, 33 EcologICAL ECON. 185, 187 (2000) (noting that "almost every scholar and policy maker from the developing world" supports factoring differences in historical emissions into a comprehensive climate change agreement).

163. For an overview of the Chinese position, see Nat'l Dev. \& Reform Comm'n of the People's Republic of China, China's National Climate Change Programme (June 2007), available at http://www. ccchina.gov.cn/WebSite/CCChina/UpFile/File188.pdf. For an analysis of the Chinese position, see Eric A. Posner \& Cass R. Sunstein, Climate Change Justice, 96 GEO. L.J. 1565, 1602-11 (2008). 
cusing on total emissions: China's current per capita emissions are only onesixth of that of the United States. ${ }^{164}$

China's position on international human rights can also be seen through the lens of developmentalism. Contesting the Western idea that political and civil rights take precedence, China argues that these rights must be subordinated when they conflict with measures that promote economic growth and maintain political stability that is necessary for growth.

\section{Institutional structure: authoritarianism}

Insisting on respect for the diversity of political, cultural, and social systems, ${ }^{165}$ China has resisted the ideals of democratic governance that threaten the core values of the one-party state and the Chinese government's ability to secure domestic political and social stability. ${ }^{166}$ Thus, the Chinese notion of human rights is tilted in favor of economic and social rights at the expense of civil and political rights. As Gerald Chan has observed:

Under China's political structure and culture, human rights are granted by the state and can easily be taken away by the state. If individual human rights run against state interests, the latter will usually prevail. ${ }^{167}$

International norms that protect political rights pose the greatest threat to the stability of the Chinese government. China may fear that consenting to any such norms would establish a focal point for dissident activity and lead to a more visible demand for political freedoms - a development that would resemble the signing of the Helsinki Accords, a 1975 agreement between the Western countries and the Soviet bloc countries, which was widely seen to have fueled political dissident activity in the Soviet satellites and ultimately contributed to the collapse of communism. ${ }^{168}$

The United States and other Western democracies have long predicted that China's receptiveness to economic globalization and liberal market institutions would spur political change in China. ${ }^{169}$ Yet the link between

164. See Vandenbergh, supra note 161, at 917.

165. See, e.g., Ministry of Foreign Affairs of the People's Republic of China, Joint Statement of the People's Republic of China and the Russian Federation on Major International Issues (May 23, 2008), available at http://www.fmprc.gov.cn/eng/zxxx/t465821.htm.

166. Foot, supra note 136, at 17.

167. Ivan Rasmussen, Torture in the United States and China: Comparing American and Chinese Exceptionalism with Respect to the United Nations Convention Against Torture, 2 Asian J. Pub. Aff. 65, 69 (2009) (citing Gerald Chan, China's Compliance in Global Affairs: Trade, Arms Control, Environmental Protection, Human Rights 177 (2006)).

168. For an argument that the Helsinki Accords helped delegitimize communist states, see generally Daniel C. Thomas, The Helsinki Effect: International Norms, Human Rights, and the Demise of Communism (2001). In particular, Article 7 of the Helsinki Accords calls for "respect for human rights and fundamental freedoms" and argues for the guarantee of the freedoms of thought, speech, conscience, religion, and faith of all citizens of the signatory states, including the communist states. See Conference on Security and Co-Operation in Europe Final Act, Aug. 1, 1975, 14 I.L.M. 1292, 1295. 169. See Ying Ma, China's Stubborn Anti-Democracy, 141 Pol'y Rev., Feb.-Mar. 2007, at 3, 4-5. 
economic liberalization and democratization in China has proved to be elusive. China has enjoyed economic benefits from liberal international institutions while resisting any political liberalization that was expected to follow from its increasing international engagement. The Chinese government has also nurtured a sentiment among its citizenry that Western-style democracy would be unsuitable for China's current economic conditions. According to the government, embracing civil and political rights incorporated in international human rights treaties would destabilize Chinese society and endanger its pursuit of economic welfare for the benefit of its citizens. ${ }^{170}$ This idea has resonated with many Chinese citizens, who want to avoid China undergoing the social instability, weak economic growth, and declining national influence that Russia experienced after the Soviet Union collapsed. The Chinese citizenry's support for the current regime is also fueled by some degree of nationalism and anti-Americanism, making it more receptive to authoritarianism and skeptical of the "imposition" of American-style democracy through international norms. ${ }^{171}$ Authoritarianism has also persisted as Western powers have pursued economic engagement with China rather than trying to influence China's human rights policies.

Despite its skepticism of many U.N. initiatives relating to individual rights, China views the United Nations as helpful in promoting its own vision of international law. The United Nations does not pose a threat to China's authoritarian government because of the exceptional status and influence China holds within the organization. As a permanent member of the Security Council, armed with a veto right, China knows that it can singlehandedly prevent any U.N. action that adversely affects China's interests. The United Nations is not a democratic organ, and that suits China. Rather, the United Nations is a forum where China enjoys an equal voice with the other great powers. The Security Council seat also provides China its most effective means to balance and constrain U.S. power. ${ }^{172}$ China is therefore eager to maintain the current structure of the U.N. system and offers its unwavering support for the authority of the Security Council. ${ }^{173}$

170. See id. at $10-11$.

171. Id. at 11 .

172. See Foot, supra note 111, at 92.

173. Ministry of Foreign Affairs of the People's Republic of China, Keynote Speech by Assistant Foreign Minister Shen Guofang, Towards an Enhanced Role of the UN Security Council in Maintaining International Peace and Security (Nov. 21, 2003), available at http://www.fmprc.gov. cn/eng/xwfw/zyjh/ t45317.htm. 


\section{American Exceptionalism Revisited: Pro-Market Democracy}

\section{A. American exceptionalism defined}

\section{Negative liberties and markets}

The United States has a longstanding commitment to political and civil rights. These commitments are reflected in the U.S. attitude toward human rights treaties. The United States has ratified the ICCPR, the human rights treaty that embodies the standard list of civil and political rights. ${ }^{174}$ It has refused to ratify the ICESCR, the human rights treaty that embodies the standard list of social, economic, and cultural rights. ${ }^{175}$ The U.S. approach to other human rights treaties fits this pattern. The United States has ratified the Torture ${ }^{176}$ and Genocide Conventions, ${ }^{177}$ since the rights to be free from torture and genocide are derived from civil and political rights that prohibit the government from abusing its citizens. Other treaties that concern social rights (for example, those promoting the rights of children and disabled persons), which the United States defines more narrowly, have not been ratified.

These commitments are also reflected in American foreign policy. ${ }^{178}$ The U.S. State Department compiles an annual report that criticizes foreign countries for violating human rights. Each country report follows a template that focuses on civil and political rights-including free speech and association, religious freedom, torture, and voting-and ignores social and economic rights such as education, health care, and social insurance. ${ }^{179}$ The only exceptions to this pattern are that the reports have a section on the right to

174. International Covenant on Civil and Political Rights, Dec. 19, 1966, 999 U.N.T.S. 171. Among other rights, the ICCPR prohibits slavery, torture, and cruel, inhuman, or degrading treatment or punishment, guarantees the rights to liberty and personal security, ensures legal procedural rights, including the rights to a fair and public hearing by a competent, independent, and impartial tribunal established by law, and guarantees the right to be presumed innocent until proved guilty according to law, and the right to be informed promptly and in detail in a language that the defendant understands of the nature and cause of the charge against him or her.

175. International Covenant on Economic, Social and Cultural Rights, Dec. 16, 1966, 993 U.N.T.S. 3. These rights include the rights to work, health care, social security, welfare, and education.

176. Convention Against Torture and Other Cruel, Inhuman or Degrading Treatment or Punishment, Dec. 10, 1984, 1465 U.N.T.S. 113.

177. Convention on the Prevention and Punishment of the Crime of Genocide, Dec. 9, 1948, 78 U.N.T.S. 277.

178. See, e.g., The White House, The National Security Strategy of the United States of America 45-46 (2006) ("Abroad, we will work with our allies on three priorities: [1.] Promoting meaningful reform of the U.N., including ... [r] reinvigorating the U.N.'s commitment, reflected in the U.N. Charter, to the promotion of democracy and human rights ... . [2.] Enhancing the role of democracies and democracy promotion throughout international and multilateral institutions, including: [s]trengthening and institutionalizing the Community of Democracies, [f]ostering the creation of regional democracy-based institutions in Asia, the Middle East, Africa, and elsewhere, [and i]mproving the capacity of the U.N. and other multilateral institutions to advance the freedom agenda through tools like the U.N. Democracy Fund .....").

179. See, e.g., U.S. Dep't of State, 2008 Country Reports on Human Rights Practices, available at http:// www.state.gov/g/drl/rls/hrrpt/2008/index.htm. 
unionize, which falls somewhere between an economic right (to representation in the workplace) and civil right (to associate), and occasionally mention child welfare issues. The reports do not comment on these omissions, which would appear quite substantial to the many countries that have ratified the ICESCR and related treaties. The unstated assumption is that the American conception of human rights is the same as the international human rights addressed in the reports.

The United States has not consistently put economic and military pressure on countries that violate civil and political rights. Like other countries, it makes exceptions for friends and other important countries with which it must do business. For example, in 1993 President Clinton granted trade concessions to China subject to China improving its human rights protections. ${ }^{180}$ A year later, however, President Clinton backed down from linking China's trading status to human rights in order to pursue a "new path" in U.S. relations with China. ${ }^{181}$ Delinking human rights from trade was motivated by the U.S. desire to secure China's cooperation in persuading North Korea not to develop nuclear weapons. The United States also wanted to make sure it did not lose large trade deals, including the Chinese government's aircraft orders, by insisting on progress on civil and political rights in China. ${ }^{182}$

U.S. international rhetoric relentlessly promotes democracy, and has been doing so at least since the administration of Woodrow Wilson. In his Fourteen Points speech that justified American entry into World War I, Wilson stressed the right to self-determination, which has since been understood to mean that nations should govern themselves by democratic means. ${ }^{183}$ This right appeared in the Atlantic Charter of 1941, which laid out the American (and British) goals in World War II. ${ }^{184}$ Throughout the Cold War, the United States described itself as the leader of the "free world"-in other words, that part of the world in which democracy flourished. In a famous article written in 1979, Jeane Kirkpatrick, a future U.N. ambassador under President Ronald Reagan, justified American support for dictatorships in the Cold War on the ground that merely authoritarian governments (as opposed to communist governments) might eventually democratize. ${ }^{185}$

180. See R.W. Apple, Jr., The Pacific Summit; Godfather to Pacific Era? Clinton Succeeds by Merely Getting Asians to Meet, N.Y. Times, Nov. 21, 1993.

181. President William J. Clinton, Press Conference on China MFN Status 5/26/94 (May 27, 1994), available at Westlaw 1994 WL 209851.

182. See John H. Jackson et al., Legal Problems of International Economic Relations 1065 (5th ed. 2008).

183. See President Woodrow Wilson, Fourteen Points (Jan. 8, 1918), available at http://www.our documents.gov/doc.php? doc $=62 \&$ page $=$ transcript.

184. Atlantic Charter, Declaration of Principles issued by the President of the United States and the Prime Minister of the United Kingdom, U.S.-U.K., Aug. 14, 1941, 55 Stat. 1600, available at http:// www.nato.int/cps/en/SID-2788FECD-8FACF71E/natolive/official_texts_16912.htm.

185. Jeane J. Kirkpatrick, Dictatorships and Double Standards, Comment., Nov. 1979, at 34, 37. 
The collapse of communism and the end of the Cold War did not change the American stance on democracy. Indeed, the U.S. government over three administrations has made a concerted effort to claim that democracy is a norm of international law. The Clinton Administration declared its commitment to promote democracy in Bosnia and Herzegovina, among other places. ${ }^{186}$ The Bush Administration's "freedom agenda" sought to promote democracy in the Middle East. ${ }^{187}$ This policy supplied one of the rationales for the Iraq War. As a presidential candidate, Barack Obama also declared his support for promotion of democracy abroad, and in the first few months of his administration, officials have expressed this policy on multiple occasions. ${ }^{188}$

The United States has also promoted free trade and free markets for more than half a century. The U.S. government initiated the GATT/WTO system in $1948,{ }^{189}$ and its commitment to maintaining and expanding this system has never wavered. During the Cold War, the United States distinguished itself from the Soviet Union in part on the basis of its commitment to markets. During this period, the United States was also the leading critic of redistributive claims made by developing countries. With the collapse of communism, the "Washington Consensus" emerged, a bundle of policy prescriptions that emphasized macroeconomic stability, fiscal discipline, privatization of government-owned resources, and liberalization of the economy. ${ }^{190}$ The United States, predominantly through the IMF and the World Bank, pressured developing countries to adopt these policies, often making loans conditional on significant reform in these directions. American institution-building after the Cold War-including the expansion of NATO, the inauguration of the North American Free Trade Agreement and the Asia Pacific Economic Cooperation, and the development of the GATT

186. See Joint Statement Released in Conjunction with the U.S.-EU Summit, Human Rights and Democratization Priorities in Bosnia and Herzegovina (Dec. 5, 1997), available at http://www.state.gov/ www/regions/eur/eu/971205_useu_bosnia_hr.html ("The United States and the European Union have thus decided to coordinate their efforts to enhance their means to work with the parties in a constant dialogue with the aim of promoting democratic normalization and the stabilization of the region.").

187. See Tamara Cofman Wittes \& Sarah E. Yerkes, What Price Freedom? Assessing the Bush Administration's Freedom Agenda, Analysis Paper No. 10, The Saban Center for Middle East Policy at The Brookings Institution (Sept. 2006), available at http://www.brookings.edu/ /media/Files/rc/papers/2006/09middle east_wittes/wittes20060901.pdf.

188. See, e.g., Deputy U.S. Secretary of State James B. Steinberg, Remarks at the 5th Community of Democracies Ministerial (July 12, 2009), available at http://www.state.gov/s/d/2009/126052.htm (asserting before the Community of Democracies delegates that "[o]ur common efforts reinforce the universality of the democratic values and serve as a powerful response to those who would argue that democracy belongs only to one region, or history or tradition" and listing the many regional "democratic backtracking" mechanisms in the AU, OAS, EU, OSCE, and ASEAN).

189. World Trade Organization, The GATT Years: From Havana to Marrakesh, available at http://www. wto.org/english/thewto_e/whatis_e/tif_e/fact4_e.htm (last visited Nov. 6, 2010).

190. Dani Rodrik, Goodbye Washington Consensus, Hello Washington Confusion?, 44 J. Econ. LiterATURE 973, 973-74 (2006). 
system with the creation of the WTO_-was designed to entrench American political and economic values as global values. ${ }^{191}$

\section{Military force to maintain global order}

The United States believes in the use of military force in order to maintain global order and, less explicitly, to advance democracy and human rights. During the Cold War, the United States pursued a policy of containment of the Soviet Union-an effort to prevent the Soviet Union from extending its influence into other countries. The policy took two forms: bolstering allies and undermining enemies, often with covert operations, including the rendering of assistance to indigenous insurgencies. During the Cuban missile crisis, the United States explicitly used military force in violation of the U.N. Charter when it blockaded Cuba (a traditional act of war); other interventions in Latin America were also unilateral. After the Cold War, the United States turned its focus on "rogue states" that engaged in illegal conduct, and used force, or threatened to use force, against Panama, Iraq, Iran, and North Korea.

In general, the United States has tried to give legal justifications for its use of force. It has frequently cited authority under the U.N. Charter. The Korean War had Security Council authorization. American participation in the Vietnam War occurred at the invitation of the South Vietnamese government; hence, it was an example of collective self-defense, which is authorized by the U.N. Charter. The Gulf War had Security Council authorization. So did the invasion of Afghanistan in 2001. The Iraq War of 2003 was not explicitly authorized by the Security Council, but the United States went to great lengths to justify the use of force on the basis of Security Council resolutions that suspended hostilities against Iraq at the end of the 1991 war, conditional on Iraqi cooperation in an inspection regime, which did not take place. ${ }^{192}$

However, the United States has not always derived its authority from the U.N. Charter. As noted above, in 1999 the United States, along with the other NATO countries, launched an air attack on Serbia that resulted in Serbia withdrawing from the renegade province of Kosovo, which it had been trying to bring under its control. Serbia had long been regarded as a troublemaker in the Balkans and had sowed disorder through its aggressive military posture during the collapse of Yugoslavia from 1991 to the Dayton

191. See G. John Ikenberry, After Victory: Institutions, Strategic Restraint, and the ReBuilding of Order after Major Wars 215-56 (2001).

192. See, e.g., President George W. Bush, Address to the Nation on Iraq, 39 Weekry Comp. Pres. Doc. 338, 338-39 (Mar. 17, 2003) ("Under [Security Council] Resolutions 678 and 687 . . the United States and our allies are authorized to use force in ridding Iraq of weapons of mass destruction. This is not a question of authority. It is a question of will."); U.S. Secretary of State Colin Powell, Presentation to the United Nations Security Council, U.N. SCOR, 58th Sess., 4701st mtg. at 2-17, U.N. Doc. S/PV.4701 (Feb. 5, 2003) (arguing that Iraq's failure to comply with Security Council Resolution 1441 warranted military action against Iraq). 
Peace Accord of 1995.193 The collapse of stability in the region had immediate harmful impacts on European countries, which had to deal with refugees. In addition, there was a great deal of pressure to stop the atrocities that were taking place on all sides. The 1999 invasion had a number of motives-to support European allies, to prevent Serbians from ethnically cleansing Kosovo of its Albanian stock, and to punish an international troublemaker. The invasion lacked Security Council authorization. ${ }^{194}$

The United States did not always take a consistent line on its legal rationales for the use of military force. But the most common themes were: Security Council authorization; self-defense (including collective self-defense); and protection of democratically elected governments (and sometimes authoritarian governments) from foreign aggression. The Bush Administration claimed at various points the right to launch preemptive or preventive wars in self-defense. But the Bush Administration and previous administrations never claimed that the United States has the exclusive right to go to war for these purposes; the arguments were always made in universalistic terms. ${ }^{195}$

Similarly, the American attitude toward international criminal law has been expressed in universalistic rhetoric. The United States refused to ratify the Rome Statute and has expressed unhappiness with a range of domestic statutes in foreign countries that permit prosecution of international crimes on the basis of universal jurisdiction. ${ }^{196}$ In both cases, the United States feared politically motivated prosecutions of American soldiers and politicians. It does not trust an international body and foreign governments to treat Americans fairly. But the United States never sought an exemption for Americans alone. ${ }^{197}$ Its original conception of the ICC was that its authority would be conditional on Security Council authorization. Once such authori-

193. See Warren Zimmermann, The Last Ambassador: A Memoir of the Collapse of Yugoslavia, ForeIGN Aff., Mar.-Apr. 1995, at 2, 12-14 (relating a personal account of the dissolution of Yugoslavia).

194. President Clinton contended that Security Council Resolutions 1199 and 1203 implicitly granted authority for military intervention by affirming "that the deterioration of the situation in Kosovo constitutes a threat to the peace and security of the region." Walter Gary Sharp, SR., Jus Paciarii: Emergent Legal Paradigms for U.N. Peace Operations in the 21st Century 313-14 (1999). The United Kingdom, Germany, and Belgium argued that authorization was unnecessary since intervention supported "the values represented in Article 2(4)." James P. Terry, Rethinking Humanitarian Intervention after Kosovo: Legal Reality and Political Pragmatism, Army Law., Aug. 2004, at 36, 45.

195. For instance, on the eve of the invasion of Panama in 1989, President George H.W. Bush argued that " $[\mathrm{t}]$ he deployment of U.S. Forces is an exercise of the right of self-defense recognized in Article 51 of the United Nations Charter ..." and that the United States has often cast the use of military force by the United States in terms consistent with the U.N. Charter. George H.W. Bush, Letter to the Speaker of the House of Representatives and the President Pro Tempore of the Senate on United States Military Action in Panama, 2 Pub. Papers of George H.W. Bush 1734 (1989).

196. See Chitra Ragavan, A Different Brand of Warfare: How Cross-Border Legal Moves are Giving the White House Lots to Worry About, U.S. News \& World Report, Mar. 19, 2007.

197. The United States began seeking bilateral immunity agreements after other countries ratified the Rome Statute. See Coalition for the International Criminal Court, Status of US Bilateral Immunity Agreements (BIAs), available at http://www.iccnow.org/documents/CICCFS_BIA status_current.pdf (last visited Nov. 6, 2010). 
zation was secured, the ICC would be able to prosecute anyone in any country.

\section{B. Explaining American exceptionalism}

\section{Domestic policy preferences: markets, liberty, democracy}

The United States is one of the world's oldest continuous democracies, and democratic principles are deeply embedded in the political culture. The negative liberties laid out in the Bill of Rights have also been internalized by Americans and American institutions. The United States' commitment to free markets has helped make it the most powerful economy in the world. Although this commitment to the market is often exaggerated-local regulation is as old as the country, and national regulation of the market has made significant inroads on laissez-faire economics since the start of the twentieth-century-there is no doubt that Americans are more committed to markets than people in other advanced democracies. ${ }^{198}$ The American economy is also among the least regulated. ${ }^{199}$

Americans are also more optimistic about, and tolerant of, war than people living in other advanced democracies, particularly those in Europe. This can in part be attributed to different historical experiences. The United States emerged as a victor of World War I, and even a more decisive victor of World War II. In World War I, it suffered battle deaths of 116,516 soldiers. ${ }^{200}$ In comparison, France lost 1,385,000, Germany lost 1,773,700, Britain lost 908,371, and Russia lost 1,700,000. ${ }^{201}$ In World War II, the United States also had significant casualties_-405,400 missing or killedbut far less than Germany (3.5 million missing or killed), Japan (1.7 million missing or killed), and Russia ( 7.5 million missing or killed). ${ }^{202}$ While cities throughout Europe were destroyed by the fighting, the U.S. mainland was virtually untouched. ${ }^{203}$ Europeans suffered from refugee crises, hunger, and austerity in the aftermath of the war; American civilians, on the other hand,

198. See, e.g., Private vs. State Ownership of Business, World Values Survey, http://www.wvsevsdb. com/wvs/WVSAnalizeQuestion.jsp (last visited Nov. 6, 2010) (To access data, navigate to "Online Data Analysis" subpage, click on "Begin Analysis," select the "WVS 2005-2008" hyperlink, select all countries to analyze and click on "Confirm Selection," and then follow the "Private vs. State Ownership of Business" hyperlink).

199. See, e.g., Simeon Djankov et al., The Regulation of Entry, 117 Q. J. Econ. 1, 18 (2002).

200. Meredith R. Sarkees, Correlates of War Inter-State War Data, 1816-1997 (v3.0), http://www.correl atesofwar.org/cow2data/WarData/InterState/Inter-State War Participants (V 3-0).csv (last visited Nov. 6, 2010); see generally Meredith R. Sarkees \& Phil Schafer, The Correlates of War Data on War: An Update to 1997, 18 Conflict Mgmt. \& Peace Sci. 123 (2000) (describing inter-state war data set).

201. Sarkees, Correlates of War Inter-State War Data, 1816-1997 (v3.0), supra note 200.

202. Id. Fighting in both the European and Pacific theatres, the United States still suffered fewer battle deaths than Britain ( 418,765 missing or killed). $I d$. France's military only lost 2500 (missing or killed); however, since it was occupied after 1940, subsequent losses were only suffered by the forces in exile at the time of occupation. See id.

203. The United States suffered essentially no civilian deaths; Britain, separated from continental Europe by the English Channel, had 60,600 killed as a result of aerial bombing; and Germany and Russia exited the war with 2.35 million and 6.7 million civilians dead, respectively. JOHN ELLIs, WorLd WAR 
enjoyed an economic boom. Since then, the United States has fought a number of "small" wars-many of them frustrating and inconclusive, with one defeat in Vietnam. But in none of these wars did the United States lose more soldiers than France did in the World War I battle of Verdun alone (which resulted in the deaths of over 60,000 French soldiers). ${ }^{204}$

Europeans and Americans derived different lessons from these experiences. In Europeans one finds a deep strain of pacifism which is almost unknown in the United States. While European governments joined NATO and fought in a few small wars, anti-militarism continues to dominate, particularly on the Continent. Note, however, that anti-militarism has not spread beyond Europe (with the exception of Japan). China, Russia, India, Israel, and many other countries have maintained strong armies and fought major wars since World War II-and China and Russia have suffered in twentieth-century wars to a degree comparable to that of European countries.

\section{Institutions: populist democracy and powerful military}

From an institutional standpoint, three features about the United States stand out: it is a democracy; it supports a market economy; and it has an enormous military. We have already discussed the first two features: they reflect public opinion rooted in tradition. More than that, they are institutions that are widely regarded as successful. It seems natural for Americans to urge other countries to adopt similar institutions.

But institutions matter in other ways. Democratic peace literature suggests that democracies do not go to war with other democracies, but instead with non-democracies. ${ }^{205}$ If this pattern reflects causal factors, then it is not surprising that democracies would want other countries, if possible, to be democracies. The absence of war may be just one manifestation of a deeper affinity among democracies, which allows them to cooperate in many ways. Similarly, countries with developed market institutions may prefer to deal with similar countries; trade is no doubt easier when institutions resemble each other and reflect market imperatives. European integration, which began as a customs union but progressed toward a single market, has reflected these pressures. The U.S. government may thus seek to encourage other

II: A Statistical Survey: The Essential Facts and Figures for All the Combatants 253-54 (1993).

204. 4 World War I EnCyClopedia 1222 (Spencer C. Tucker et al. eds., 2005).

205. See, e.g., Bruce Russett, Grasping the Democratic Peace: Principles for a Post-Cold War World (1993). The U.S. government seems to agree. See The White House, A National Security Strategy for a New Century 2 (1998) (“In designing our strategy, we recognize that the spread of democracy supports American values and enhances both our security and prosperity. Democratic governments are more likely to cooperate with each other against common threats, encourage free trade, and promote sustainable economic development. They are less likely to wage war or abuse the rights of their people. Hence, the trend toward democracy and free markets throughout the world advances American interests. The United States will support this trend by remaining actively engaged in the world.”). 
countries to adopt American-style institutions because cooperation with such countries becomes easier and more beneficial.

The EU shares the United States' commitment to democracy. But this shared commitment masks different political cultures. In European countries, the public tends to defer to self-perpetuating political and bureaucratic elites. Elections are referenda on the performance of the governing party; the political leaders themselves work their way up the party hierarchy. American democracy has a strong populist skepticism of elites. The political class is easily penetrated by unknowns who ride a wave of populist enthusiasm (Jimmy Carter, Barack Obama, Sarah Palin, Ross Perot)_an almost unheard-of phenomenon in Europe, where populists are kept at the fringes. ${ }^{206}$ The EU itself is governed by a bureaucratic elite appointed by the political elites of its member states. Efforts to overcome this widely recognized "democratic deficit" by transferring power to the European Parliament have so far been unsuccessful. ${ }^{207}$

This divide may explain why European countries support international institutions more readily than the United States does. These institutions, like the EU itself, are staffed by the same kind of elite politicians that govern European countries. Europeans, accustomed to deferring to their leaders, also defer to the international institutions those leaders create and staff. Americans, by contrast, distrust their leaders. Fearing a backlash from the voters, American politicians are reluctant to insist that those voters submit to another, even more remote layer of bureaucratic governance at the international level.

The third institutional feature mentioned above-the enormous military-also sets the United States apart from other states. It is an understatement to say that the United States is the most dominant military power in the world. In 2005, the United States spent $\$ 503$ billion on military expenditures, almost half of the $\$ 1.16$ trillion spent worldwide. ${ }^{208}$ As Table 1 shows, in absolute terms U.S. spending dwarfs the amounts spent on the nine next most expensive militaries. ${ }^{209}$ This was not always the case. The United States was a military weakling in the nineteenth-century up until World War I. But wealthy, populous countries can become military powers,

206. While some European populists have risen to prominence in recent years, such as Joerg Haider, Jean Marie Le Pen, and Geert Wilders, this position remains the exception more than the norm, as it is in the United States. These populist figures have also remained marginal in European politics; they have not obtained (or kept) real political power like their counterparts in the United States. For an overview of the greater prevalence of American populism compared to Europe, see Steiker, supra note 93, at 114-17.

207. See Rabkin, supra note 77, at 274.

208. U.S. Dep't of State, World Military Expenditures and Arms Transfers 2005, available at http://www. state.gov/documents/organization/121776.pdf.

209. In relative terms, however, the United States spends only 4.06 percent of its GDP on military expenditures, which ranks it 25 th out of the 173 countries ranked by the CIA. Central Intelligence Agency, The World Factbook, Country Comparison: Military Expenditures, available at https://www.cia.gov/ library/publications/the-world-factbook/rankorder/2034rank.html (last visited Nov. 6, 2010). 
and the United States did so during World War II. Since then, its only rival has been the now-defunct Soviet Union.

Table 1: Countries with the Highest Military EXPENDITURES, 2005210

\begin{tabular}{|c|c|}
\hline Country & Military Expenditures (Billions) \\
\hline United States & $\$ 503.0$ \\
\hline China & $\$ 85.3$ \\
\hline United Kingdom & $\$ 55.9$ \\
\hline France & $\$ 52.9$ \\
\hline Japan & $\$ 43.9$ \\
\hline Germany & $\$ 38.1$ \\
\hline Italy & $\$ 33.5$ \\
\hline Russia & $\$ 31.1$ \\
\hline Saudi Arabia & $\$ 25.4$ \\
\hline India & $\$ 18.8$ \\
\hline
\end{tabular}

The United States maintained an enormous military during the Cold War because of the Soviet threat. Accordingly, people believed that the collapse of the Soviet Union would deliver a "peace dividend" in the form of smaller budgets. The era of small military budgets was brief, however, as it became clear that the United States could use military force to achieve its foreign policy aims. Indeed, the United States became embroiled in several more wars after the end of the Cold War, culminating in the conflict with $\mathrm{Al}$ Qaeda.

It is hardly surprising, then, that the United States would try to protect its freedom to use military force, just as it is not surprising that the United States would seek to duplicate its democratic and market institutions in foreign countries. It is playing to its institutional strengths. But in taking these positions, the United States uses universalistic rhetoric. It does not claim that the United States alone should be able to use its military; rather, all countries have the same right to resort to military force under defined circumstances. ${ }^{211}$ Similarly, democracy and free markets are not just the pre-

210. U.S. Dep't of State, supra note 208.

211. For a statement of these circumstances, see The White House, National Security Strategy 22 (2010) (stating that force "may be necessary to defend [the United States] and allies or to preserve broader peace and security, including by protecting civilians facing a grave humanitarian crisis," and that the United States will "exhaust other options before war whenever [it] can," "seek broad international support" when force is used, but "reserve[s] the right to act unilaterally if necessary [for defense]"). 
rogatives of the United States: all people should have access to democratic and market institutions.

\section{Are Exceptionalist States also Exemptionalist?}

We have argued that the great powers-including the United States, the EU, and China-advance their exceptionalist views of international law in ways that reflect their distinctive values and serve their particular interests. None of the exceptionalist states, however, calls for a different set of rules that would apply to that state alone. Instead, each calls for a universal application of the international rules embedding its respective exceptionalist vision. This is the key distinction between exceptionalism and exemptionalism.

\section{A. Rejecting American, European and Chinese exemptionalism}

In Part I, we disputed the contention that the United States is exemptionalist. As we noted, there are no examples of the United States explicitly arguing that it is exempt from the rules that apply to other countries. Like other great powers, the United States advances a particular vision of international law that reflects its values, serves its interests, and takes advantage of its institutional capacities. But its vision is universal, in the sense that the rules and interpretations it advances are the same for all countries. ${ }^{212}$ The United States has frequently insisted that its norms and practices should

212. The U.S. leaders often emphasize the United States' unique role and leadership in the world, which may-mistakenly, in our view-be perceived as evidence of American exemptionalism. See President Barack Obama, Acceptance Speech for the Nobel Prize in Peace (Dec. 10, 2009) (transcript available at http://www.whitehouse.gov/the-press-office/remarks-president-acceptance-nobel-peace-prize) ("The United States of America has helped underwrite global security for more than six decades with the blood of our citizens and the strength of our arms. The service and sacrifice of our men and women in uniform has promoted peace and prosperity from Germany to Korea, and enabled democracy to take hold in places like the Balkans. We have borne this burden not because we seek to impose our will. We have done so out of enlightened self-interest-because we seek a better future for our children and grandchildren, and we believe that their lives will be better if others' children and grandchildren can live in freedom and prosperity."); see also President George W. Bush, State of the Union Address (Jan. 29, 2002) (transcript available at http://millercenter.org/scripps/archive/speeches/detail/4540) ("And we have a great opportunity during this time of war to lead the world toward the values that will bring lasting peace .... America will lead by defending liberty and justice because they are right and true and unchanging for all people everywhere .... We have no intention of imposing our culture. But America will always stand firm for the nonnegotiable demands of human dignity . . . .); President William J. Clinton, Address on Bosnia (Nov. 27, 1995) (transcript available at http://millercenter.org/scripps/ archive/speeches/detail/3929) ("From our birth, America has always been more than just a place. America has embodied an idea that has become the ideal for billions of people throughout the world . . . In this century especially, America has done more than simply stand for these ideals. We have acted on them and sacrificed for them. Our people fought two World Wars so that freedom could triumph over tyranny .... After World War II, we continued to lead the world. We made the commitments that kept the peace, that helped to spread democracy, that created unparalleled prosperity, and that brought victory in the cold war . . . . Today, because of our dedication, America's ideals-liberty, democracy, and peaceare more and more the aspirations of people everywhere in the world. It is the power of our ideas, even more than our size, our wealth, and our military might, that makes America a uniquely trusted nation."). 
provide the basis for international law. This is different from the United States exempting itself from the rules that apply to other states.

It is also wrong to depict the EU as an exemptionalist power. Critics have pointed out that the EU is a champion of multilateral trade liberalization, yet the European single market is the most extreme example of trade-diverting regionalism. Similarly, the EU promotes the most-favored nation principle in the WTO, yet maintains preferential trading arrangements with former European colonies. ${ }^{213}$ But the EU is not seeking to carve out an exemption for itself. Instead, the EU claims, it takes the stand that regionalism is compatible with multilateralism; that regional trade blocks are building blocks for multilateral trade liberalization. ${ }^{214}$ Similarly, preferential trade agreements are consistent with the principle of "special and differential treatment" of developing countries. ${ }^{215}$

It is also wrong to suggest that the EU's voting practices amount to exemptionalism. ${ }^{216}$ The EU is not enjoying the privilege of double-voting. Depending on whether the issue falls under the European Community competence or the national competence, the EU either casts the votes on behalf of the member states or the member states cast their votes individually. ${ }^{217}$ The EU cannot vote independently in addition to the votes cast by member states. $^{218}$ The practice of coordinating a negotiation position yet casting individual votes is consistent with the character of the EU: the EU is not a state, but rather a tight economic community and a loose political union among twenty-seven independent nation states. That independent nation states each retain a right to vote is not exemptional.

The best argument for European exemptionalism comes from the global climate change negotiations. The EU insisted it would be treated as a single state when calculating the emissions that the EU members were entitled to

213. See Panel Report, European Communities_Regime for the Importation, Sale and Distribution of Bananas, WT/DS27/R/ECU (May 22, 1997).

214. Jacques Delors, The Future of Free Trade in Europe and the World, 18 Fordham Int'L L.J. 715, 723-24 (1995).

215. On the legal basis of this claim, see supra note 160 and accompanying text.

216. See Safrin, supra note 18, at 1328 (claiming that the EU seeks different rules for itself because of the "exceptional accommodations" its institutional structures require).

217. In the WTO, however, individual member states vote even though the external trade policy falls under the European Community's competence. This is partly justified by the expansion of the WTO to new areas, including services and intellectual property rights, where the EC and the member states share competence and where the EU could not legally exercise the vote of its individual member states. See Opinion 1/94, Re The Uruguay Round Agreements, Decision of 15 November 1994, 1994 E.C.R. I5267, I $1-3$. Consistent with their individual voting rights, all member states pay dues to the WTO based on their total trade, including intra-EU trade. Bernard M. Hoekman \& Michel M. Kostecki, The Political Economy of the World Trading System: The WTO and Beyond 56 (2d ed. 2001).

218. See, e.g., Kyoto Protocol to the United Nations Framework Convention on Climate Change art. 22, Dec. 11, 1997, 37 I.L.M. 22, available at http://unfccc.int/resource/docs/convkp/kpeng.pdf. For a sole example to the contrary, see Protocol Relating to the Madrid Agreement Concerning the International Registration of Marks, June 27, 1989, available at http://www.wipo.int/madrid/en/legal_texts/trtdocs_ wo016.html. 
under the Kyoto Protocol. ${ }^{219}$ In practice this "Kyoto bubble" meant that some EU member states' increases in emissions could be offset by emission reductions in others. ${ }^{220}$ The EU first opposed a similar arrangement within other developed countries. This, some would argue, would have amounted to EU exemptionalism. ${ }^{221}$ However, other states rejected the EU's proposal for sui generis treatment, and the EU agreed to allow emissions trading between other states as well. ${ }^{222}$ Consequently, this possible (but failed) exemptionalism in connection with the climate change negotiations aside, the argument for the EU's exemptionalism remains thin.

China has also been accused of exemptionalism. Critics point to China's insistence on differential treatment to account for its developmental needs. ${ }^{223}$ However, China does not argue that it alone should benefit from this principle. China argues that, as a general rule, international obligations should be relaxed for all developing countries (including, but not limited to, China). ${ }^{224}$ It is not a coincidence that China is among the many beneficiaries of this universal rule. No state advances international rules that are inconsistent with its national interests. But a state pursuing a universal rule that is consistent with its interests is not the same as a state that embraces exemptionalism, even if that universal rule would at times lead to a state being exempted from some international responsibilities.

219. See United Nations Framework Convention on Climate Change, Kyoto Protocol Targets, available at http://unfccc.int/kyoto_protocol/items/3145.php (last visited Nov. 10, 2010) ("The 15 States who were EU members in 1990 will redistribute their targets among themselves, taking advantage of a scheme under the Protocol known as a 'bubble', whereby countries have different individual targets, but which combined make an overall target for that group of countries.").

220. It is also questionable that the "Kyoto bubble" should be considered exemptionalist per se. When a regional trading block is formed, the WTO allows for an individual country belonging to a regional customs union or a free trade area to increase its duties and other barriers to trade as long as trade barriers on the whole will not be higher than the corresponding duties and trade barriers before the formation of the regional trading block. See General Agreement on Tariffs and Trade arts. XXIV:5(a), XXIV:5(b), Oct. 30, 1947, 61 Stat. A-11, 55 U.N.T.S. 194. The idea is the same: offsetting emissions or trade barriers is allowed as long as the EU as a whole ensures that a certain maximum level of tariffs or emissions is not exceeded.

221. Safrin, supra note 18 , at 1334-35.

222. See id. at 1332-33; cf. Convention on Biological Diversity, Open-Ended Ad Hoc Working Group on Biosafety, Individual Government Submissions on the Contents of the Future Protocol, U.N. Doc. UNEP/CBD/BSWG/Inf.2, at 93-106 (May 6, 1997), available at http://www.cbd.int/doc/meetings/bs/ bswg-02/information/bswg-02-inf-02-en.pdf (indicating that the EU proposed separate treatment for regional economic integration organizations).

223. See Safrin, supra note 18, at 1350; C. Fred Bergsten, A Partnership of Equals: How Washington Should Respond to China's Economic Challenge, Foreign AfF., July-Aug. 2008, at 58 (reporting that some have construed China's policy as "the usual free-riding and skirting of responsibility by a powerful newcomer"); cf. Stanley J. Michalak, U.N. Conference on Trade and Development, Part 5: The U.S. Must Reassess Its Role, Heritage Found. Backgrounder 477, at 7-8 (1985), available at http://www.policy archive.org/handle/10207/bitstreams/9236.pdf (accusing developing countries, generally, of keeping double standards); John N. Moore, Grenada and the International Double Standard, 78 AM. J. INT'L L. 145, 167 (1984) (arguing that the international community is more tolerant of violations of law when totalitarian regimes, generally, act purportedly for "revolutionary" or "anti-imperialist" goals).

224. See Edward Wong \& Jonathan Ansfield, China Insists That Its Steps on Climate Be Voluntary, N.Y. Times, Jan. 29, 2010, at A5 (noting that "China is banding together with other major developing nations to stress that only the wealthier countries need to make internationally binding commitments"). 
To illustrate the difference between exceptionalism and exemptionalism, consider income tax policy as an example from domestic law. Few would portray progressive income tax policy as a kind of exemptionalism for the poor. Most people believe that different individuals have "common but differentiated responsibilities" to pay taxes. Progressive taxation, instead, reflects a public policy based on the idea of fairness and redistribution, and can be contrasted with policies that exempt specified individuals from paying their taxes. China, similarly, does not seek to create a system that exempts China alone from its rules; rather, it seeks universal commitment to a "progressive" system of international law with development-adjusted rights and responsibilities.

China is not the sole beneficiary of the developmentalist international order. The World Bank classifies only sixty-nine countries as high-income countries. ${ }^{225}$ The rest are commonly viewed as developing countries. China also acknowledges that some countries are appropriately perceived as "least developed countries" that are entitled to even greater flexibilities than China and other "wealthier developing countries." 226 Also, assuming that China can maintain its trajectory of economic development, China will one day lose its status as a developing country. Nothing in China's international law rhetoric suggests that any country, China included, would have an inherent or lasting basis of claiming a right to special and differential treatment.

\section{B. Exemptionalism and violation of international law}

One might argue that states' rhetoric is immaterial; what matters instead is their behavior. The United States is exemptionalist because it violates international law that does not suit its interests. It hardly matters that the United States does not admit that it violates international law, or does not claim a de jure privilege to violate international law that binds others. Behind the rhetoric, the United States engages in de facto exemptionalism.

225. See The World Bank, Country and Lending Groups, available at http://go.worldbank.org/D7SN 0B8YU0 (last visited Nov. 6, 2010).

226. China suggested this differentiation between developing countries during international climate change negotiations. See Press Release, National Development and Reform Comm'n of the People's Republic of China, Implementation of the Bali Roadmap: China's Position on the Copenhagen Climate Change Conference (May 20, 2009), available at http://en.ndrc.gov.cn/newsrelease/t20090521_2803 82.htm (stating that least developed countries, particularly among developing countries, need assistance adapting to climate change); Sun Xiaohua et al., African Nations Will Stay at the Table, China DaILY, Dec. 15, 2010, available at http://www.chinadaily.com.cn/world/2009-12/15/content_9179402.htm (reporting China's preference for least developed countries to receive preferential treatment in receiving funds for climate change mitigation and adaption); Jim Yardley, China Says Rich Countries Should Take the Lead on Global Warming, INT'L Herald Trib., Feb. 7, 2007. Nor is China alone in making this distinction. India has also suggested that not all developing countries should be treated alike in international negotiations on climate change. See Rama Lakshmi, India's Carbon Fighters Must Wait, Wash. Post, Oct. $19,2009$. 
The problem with this argument is that all states violate international law some of the time. For the United States, the bill of particulars includes the 2003 Iraq War, the 1999 Kosovo War, torture and extraordinary rendition in connection with the war on terror, and a number of trade violations. For the EU, there is a similar list-the 1999 Kosovo War, complicity in extraordinary rendition, trade violations, and-for a substantial group of member states - the 2003 Iraq War. For China, an authoritarian state, one can point to extensive human rights violations, including the suppression of political dissent and religious freedom. Ordinary states also sometimes violate international law. Human rights violations, including torture, ${ }^{227}$ and violations of countries' WTO obligations are widespread.

Our argument is not that the United States violates international law less than other countries do. We do not seek to, or even know how to, measure and compare violations. Our argument, instead, is that, qualitatively speaking, there is nothing distinctive about the United States. Like the other major powers, and indeed like many normal states, it sometimes violates international law. Either all states are exemptionalist, in which case the term is useless, or none are.

A similar point can be made about behavior that falls short of international law violation but that is in tension with a state's exceptionalist stance on international law. As we noted earlier, many people argue that the United States engages in double standards when it coddles friendly dictators while proclaiming a commitment to human rights. The EU, of course, engages in similar behavior. Both the United States and the EU try to maintain friendly relations with China, Russia, and other authoritarian states because of their geopolitical and economic importance. These countries are simply balancing objectives that are not always consistent-prosperity and security, on the one hand, and the promotion of human rights, on the other.

China does the same thing, but in the opposite direction. Having proclaimed the inviolability of sovereignty, it has joined some resolutions condemning human rights violations in other states. ${ }^{228}$ Doing so, China is compromising its stance on international law for reputational reasons-it wants to maintain good relations with the human-rights promoting states. As we noted above, China's position on free trade and the right to development is not always carried through consistently. ${ }^{229}$

227. See, e.g., Michael J. Gilligan \& Nathaniel H. Nesbitt, Do Norms Reduce Torture?, 38 J. LegaL STUD. 445 (2009).

228. See supra note 125 and accompanying text (describing China's decision to join in condemnation of Myanmar).

229. For a book-length account of China's compliance with international law, see generally CHAN, supra note 167, at 205 (arguing that China's compliance with arms control treaties is "satisfactory," with trade treaties is "good," with human rights treaties is "fair to poor," and with environmental protection treaties is "poor"). 
In sum, all states have multiple objectives that are in tension with one another. The compromises that result are simply normal politics, not special behavior that deserves the label of exemptionalism.

\section{Embedded exemptionalism in international law}

The above discussion has shown that none of the exceptionalist states are explicitly exemptionalist. In forgoing exemptionalism, however, exceptionalist states do not forgo their own interests. Exceptionalist states consistently take advantage of international institutions that are constructed in ways that favor them. They have been central in creating-and remain essential in maintaining - international institutions that embody their influence and preferences. The formation of international institutions has enabled exceptional states to create hierarchies, reinforce privileges, and institutionalize their disproportionate influence over international law.

The United Nations offers the most compelling example of the presence of exemptionalism, or "double standards," in international law. The United States, United Kingdom, France, China, and Russia all enjoy a permanent seat and a right to a veto in the Security Council. The U.N. Charter explicitly sets the exceptionalist states apart from all other states and vests them with exclusive rights and responsibilities. This is the most significant departure from the principle of the sovereign equality of states. Most commentators concede that the composition of the Security Council fails to correspond to the distribution of power in today's world. ${ }^{230}$ Some further question the fairness and the legitimacy of the organization as a result. ${ }^{231}$ Still, granting the permanent five members of the Security Council a privileged position among nations remains widely accepted-if only because of the political infeasibility of any alternative: the current five permanent members are unlikely to agree to empower other states by disempowering themselves. ${ }^{232}$

A similar charge of "collective exemptionalism" or "double standards" may be lodged against the Treaty on the Non-Proliferation of Nuclear Weapons ("NPT"). The NPT divides states into nuclear and non-nuclear states and vests the two groups of states with different rights and obligations. Under the NPT, states that do not possess nuclear weapons renounce any future acquisition of such weapons and undertake to pursue nuclear

230. See, e.g., Jacob K. Cogan, Representation and Power in International Organization: The Operational Constitution and Its Critics, 103 AM. J. INT'L L. 209, 240 (2009) (listing various U.N. General Assembly discussions on whether to change the composition of the Security Council and explaining the G-4's bid for seats in the Security Council).

231. See, e.g., David D. Caron, The Legitimacy of the Collective Authority of the Security Council, 87 Aм. J. INT'L L. 552, 558-60 (1993) (explaining how perceptions of illegitimacy that arise when the organization fails to live up to its "promise and spirit" may lead to failed negotiations).

232. See Daniel W. Drezner, The New World Order, Foreign Aff., Mar.-Apr. 2007, at 35 (suggesting that European nations are unwilling to "reduce their overrepresentation in multilateral institutions"); $c$. Yehuda Z. Blum, Proposals for UN Security Council Reform, 99 AM. J. INT'L L. 632, 643-44 (2005) (analyzing the potential power struggles that would result if countries tried to add seats to the Security Council). 
technology only for civilian purposes. In contrast, states that do possess nuclear weapons (the United States, Russia, China, the United Kingdom, and France-the permanent members of the Security Council) ${ }^{233}$ undertake to pass nuclear technology to non-nuclear weapon states only for peaceful purposes. Thus, like the U.N. Charter, the NPT openly sets the exemptionalist (nuclear) states apart from normal (non-nuclear) states. However, unlike the U.N. Charter, the NPT provides for a quid pro quo. The non-nuclear states have no obligation to enter the NPT and are free to develop nuclear weapons technology without violating international law.

Similar to the United Nations, the IMF and World Bank were set up after World War II to reflect the distribution of power at that time, which disproportionally favored the United States and the European states. The Americans and Europeans designed a voting system that allowed them to dominate decision-making. Although the United States only constitutes five percent of the population of the IMF member states, it enjoys nearly seventeen percent of the votes-enough to give it a single-handed veto right over all decisions-whereas the Europeans control forty percent of the vote, despite only comprising thirteen percent of the IMF member state population. ${ }^{234}$ This is particularly striking when contrasted with the five percent voting share that China and India collectively hold. ${ }^{235}$ The voting power in the World Bank mirrors that of the IMF. ${ }^{236}$ In addition, since the founding of the Bretton Woods institutions in 1944, the Europeans have chosen the head of the IMF and the Americans have nominated the head of the World Bank. This de facto control of both institutions gives the United States and the EU special status that allows them to grant loans and debt relief based on geopolitical and ideological considerations. ${ }^{237}$

The WTO embodies a less hierarchical decision-making structure: it operates on the principle of consensus and gives all member states an equal vote. In practice, however, states with the largest economies drive the negotiation process. Similarly, the enforcement of WTO commitments remains largely the privilege of powerful states; powerful states may violate their trade commitments toward weaker trading partners, knowing that weaker states are unlikely to carry out retaliation against them even if they secure

233. India, Pakistan, North Korea, and Israel, which are either commonly known or widely believed to possess nuclear weapons, are not participants to the NPT. North Korea signed the NPT, violated it, and subsequently withdrew from it.

234. See Int'l Monetary Fund, IMF Executive Directors and Voting Power, http://www.imf.org/external/ $\mathrm{np} / \mathrm{sec} /$ memdir/eds.htm (last visited Nov. 6, 2010); Jeffrey D. Sachs, The FP Memo: Urgent: How to Run the International Monetary Fund, Foreign PoL'y, July-Aug. 2004, at 60, 61.

235. See Sachs, supra note 234, at 61.

236. See World Bank, International Bank for Reconstruction and Development: Subscriptions and Voting Power of Member Countries, http://web.worldbank.org/WBSITE/EXTERNAL/EXTABOUTUS/ORGANIZATI ON/BODEXT/0,,contentMDK:20124831 menuPK:64020035 pagePK:64020054 piPK:64020408 theSitePK:278036,00.html (last visited Nov. 14, 2010).

237. See Sachs, supra note 234, at 61 (insinuating that the current IMF managing director owes his job to the collusion of rich countries). 
the WTO's authorization to do so. ${ }^{238}$ Powerful states are therefore rarely targets of trade sanctions, ${ }^{239}$ yet are uniquely positioned to employ trade sanctions against their trade partners. ${ }^{240}$ Though the WTO rules seem egalitarian on the surface, a closer look at the operation of these rules reveals a familiar hierarchical structure, present in most international institutions.

There is a significant irony here. While the IMF, the World Bank, the WTO, and many other international institutions have been criticized for their bias toward powerful countries, the United Nations has largely avoided this charge. Yet the United Nations is the only international institution that has the power to issue orders that legally bind all states while giving a privileged group of states the power to ensure that those orders never apply to them. Reform efforts have focused on expanding the group of states with veto power-adding, for example, Germany, Japan, Brazil, or India-but not in eliminating the basic distinction between great powers with veto rights or other privileges, and ordinary states without those privileges. All states - the exceptional as well as the ordinary-appear to acquiesce in the basic premise of the Security Council: significant interventions to keep the peace require the consent of the most powerful states, but not the consent of other states.

If this system has exemptionalist overtones, it has nothing to do with exceptionalism. No single exceptional state has authority in the U.N. system; instead, authority is shared by a group of powerful states, some of them exceptional, some not. The U.N. system does not reflect any single country's distinctive vision; it reflects an overlapping consensus among the great powers and ordinary countries. ${ }^{241}$

Now let us consider again the ICC. As we noted above, the EU sought to give the ICC independent authority to initiate prosecutions and trials. The United States sought to make the ICC's authority depend on Security Council authorization, which would have given the United States (and other permanent members) a right of veto and, in effect, immunized their citizens from prosecution. It is widely agreed that the EU position was "universalistic," while the American position was exemptionalist.

If this argument is correct, it reflects a deep irony. The U.S. position was just to add the ICC to the Security Council's long list of existing powers. Thus, the argument boils down to a claim that increasing the power of the

238. See Steve Charnovitz, Rethinking WTO Sanctions, 95 Am. J. INT'L L. 792, 816-17 (2001).

239. However, the powerful exceptionalist states may still engage in trade disputes among themselves, since the threat of retaliation is credible for those countries.

240. For example, Ecuador needs access to the U.S. market much more than the United States needs access to the Ecuadorian market. Ecuador would therefore be vulnerable to U.S. sanctions whereas the United States would be only mildly harmed by retaliatory tariffs on the Ecuadorian border. Ecuador is also more likely to be dependent on U.S. imports, and the decision to restrict the entry of U.S. goods into its market is likely to hurt Ecuador much more than the United States. Thus, the United States may intentionally violate its commitments to Ecuador, knowing that Ecuador cannot follow through on its threats.

241. The same argument applies to the NPT. 
Security Council reflects an exemptionalist agenda-even though the Security Council has a high level of international legitimacy.

But there is a more serious problem with the argument. The claim that the U.S. position is exemptionalist rests on a strong distinction between de jure and de facto arguments. The United States can argue that its position is (de jure) universal because no special exception is made for AmericansAmericans would not be granted immunity under the Rome Statute as the United States envisioned it. The skeptics might respond that the United States would be given de facto immunity because of its veto in the Security Council. An exemptionalist charge, however, can also be turned against the Europeans. The Rome Statute, as ratified, is universalistic in the sense that it applies to all nations. But, de facto, it does not apply to the Europeans because relatively few European soldiers are sent into combat, and European law enforcement authorities investigate and prosecute international crimes, thus satisfying the complementarity provision of the Rome Statute. The Rome Statute would create greater risks for the United States than for Europeans because of the more frequent (and aggressive) use of military force by the former. So if the U.S. position on the Rome Statute was exemptionalist, so was the European position that was finally adopted-in the sense that both powers were determined to ensure that their own soldiers would never have to stand trial before the ICC.

Exemptionalism in this sense means a posture of advocating international treaties that place burdens on other states and no burdens, or fewer burdens, on one's own state. There are many ways to go about this argument. One could argue that obligations are contingent on the approval of an institution in which one has a veto right (the U.S. position). In contrast, one could argue that obligations are such that one's own state already satisfies them and other states do not (the European position). The principle of common but differentiated responsibilities is a third version of this idea; under this proposal, developing states are given more limited obligations than developed states. To condemn exemptionalism in this sense is to condemn all states, because all states enter treaty negotiations with an eye toward maximizing their benefits and minimizing their burdens. It is hard to make sense of exemptionalism except in the formal sense of demanding exemptions from general obligations of international law. Otherwise, charges of exemptionalism are just a complaint that a state fails to comply with international morality.

The essence of the debate over exemptionalism should now be clear. It is an attempt to transform the debate about international morality, which is endlessly contested, into a debate about formal legal compliance with the law, which can at least in principle be resolved with legal methods. But the transformation fails. If exemptionalism is understood in a substantive sense-all treaties should be "fair"-it does not differ from international morality. If exemptionalism is understood in a formal sense-all states (or 
all similarly situated states) should be subject to the same obligations-it does constrain states. Nevertheless, by advocating universal legal obligations that burden other states and do not burden themselves, states can avoid charges of exemptionalism in the formal sense without sacrificing their own interests.

\section{CONCLUSION}

There has been a long debate about American exceptionalism which, until recently, has focused on American ideology, culture, and institutions. This debate has focused on those aspects of American life that set it apart from the rest of the world; explanations have been sought in unique features of American history. Discussions about the relationship between American exceptionalism and foreign policy are more recent. Scholars have again identified what seems to be unique about the United States by focusing on American foreign policy. They have then tried to explain how these distinctive features of American foreign policy have their source in America's unique history. The foreign policy debate, unlike the original debate, has a strongly negative cast. American exceptionalism in foreign policy means that the United States does not comply with the universal rules of international law-it prefers to maximize its power or pursue idiosyncratic political ends.

Our main argument is that, although there is much to criticize in American foreign policy, exceptionalism is not a useful target of criticism. Indeed, a careful examination of the critics' arguments reveals that they are not concerned with American exceptionalism or even exceptionalism per se; instead, they disapprove of American exceptionalism, wishing that the United States displayed European exceptionalism-that is, the approach to international law that European countries have taken. This discussion has shown that most powerful states are "exceptionalist" in the sense that they seek to embody their values and interests in international law. The criticism of exceptionalism, then, is just a criticism of power, or the use of power to achieve ends of which the critic disapproves.

Stronger complaints about exemptionalism (as opposed to exceptionalism) also turn out to be unpersuasive. All states violate international law some of the time; it makes little sense to call violators exemptionalists. If exemptionalism is understood to be the posture that a state does not have to follow rules that apply to all other states, then no state is exemptionalist; the category is effectively empty. If exemptionalism is understood to be a tendency to support treaties that place greater burdens on other countries and fewer (or no) burdens on one's own country, then all states are exemptionalist. This is just a normal part of international bargaining.

The complaint that the United States, or any other state, has an exceptionalist vision of international law leads down a blind alley. The argument 
gets mired in impossible-to-answer questions about the true content of international law and the degree to which a particular state departs from it in public statements or behavior. The whole inquiry is misdirected because international law is itself the product of the overlapping consensus among states, and constantly evolves as that consensus shifts in response to new circumstances. The question is not whether a particular country's vision of international law is exceptionalist; the question is whether that vision is appealing as a matter of policy and political morality. This latter question is a much more difficult one, but it is the only question that counts. 